\title{
PREVIDÊNCIA SOCIAL
}

POLÍTICAS SOCIAIS: acompanhamento e análise 


\author{
Ministério do Planejamento, \\ Desenvolvimento e Gestão \\ Ministro Esteves Pedro Colnago Junior
}

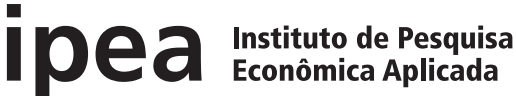

Fundação pública vinculada ao Ministério do Planejamento, Desenvolvimento e Gestão, o Ipea fornece suporte técnico e institucional às ações governamentais - possibilitando a formulação de inúmeras políticas públicas e programas de desenvolvimento brasileiros - e disponibiliza, para a sociedade, pesquisas e estudos realizados por seus técnicos.

\section{Presidente}

Ernesto Lozardo

\section{Diretor de Desenvolvimento Institucional}

Rogério Boueri Miranda

Diretor de Estudos e Políticas do Estado, das Instituições e da Democracia

Alexandre de Ávila Gomide

\section{Diretor de Estudos e Políticas \\ Macroeconômicas}

José Ronaldo de Castro Souza Júnior

Diretor de Estudos e Políticas Regionais, Urbanas e Ambientais

Alexandre Xavier Ywata de Carvalho

Diretor de Estudos e Políticas Setoriais de Inovação e Infraestrutura

Fabiano Mezadre Pompermayer

Diretora de Estudos e Políticas Sociais

Lenita Maria Turchi

Diretor de Estudos e Relações Econômicas

e Políticas Internacionais

Ivan Tiago Machado Oliveira

\author{
Assessora-chefe de Imprensa e Comunicação \\ Mylena Pinheiro Fiori \\ Ouvidoria: http://www.ipea.gov.br/ouvidoria \\ URL: http://www.ipea.gov.br
}

\section{POLÍTICAS SOCIAIS}

acompanhamento e análise

Diretoria de Estudos e Políticas Sociais

Conselho Editorial

Alexandre Arbex Valadares

Ana Cleusa Serra Mesquita

Antonio Teixeira Lima Junior

Edvaldo Batista de Sá

José Aparecido Carlos Ribeiro

Marcelo Galiza Pereira de Souza

Natália de Oliveira Fontoura

Roberto Henrique Sieczkowski Gonzalez

Colaboradores

\begin{tabular}{l|l} 
Previdência Social & $\begin{array}{l}\text { Aline Diniz Amaral } \\
\text { Graziela Ansiliero } \\
\text { Rogério Nagamine Costanzi }\end{array}$
\end{tabular} 


\section{PREVIDÊNCIA SOCIAL}

\section{APRESENTAÇÃO}

A questão da Previdência Social tem assumido vulto e espaço expressivos no debate público, muito em decorrência da proposta de reforma apresentada ao final de 2016. A Proposta de Emenda à Constituição (PEC) no 287 buscou introduzir ajustes paramétricos significativos rumo à homogeneização de regras entre os diferentes públicos e tendo em perspectiva o contexto de acelerado envelhecimento da população. Após cinco meses de discussão na Câmara dos Deputados, a Comissão Especial apresentou, em maio de 2017, um texto substitutivo que suavizou as mudanças propostas, preservando, contudo, pontos importantes, como instituição da idade mínima, aumento da carência contributiva e mudanças na regra de cálculo de aposentadorias e pensóes. Como este estudo foi desenvolvido, quase que integralmente, antes da emenda aglutinativa apresentada no final de 2017, a análise se concentra fortemente no desenho da proposta que prevaleceu até maio de 2017. Por essa razão, não foi possível analisar em maior ou com a mesma profundidade as mudanças introduzidas no final de 2017 pela referida emenda aglutinativa, tendo sido incorporada apenas breves citaçóes, tarefa que deve ser executada no próximo boletim juntamente com os futuros desdobramentos da reforma da previdência.

Este capítulo se inicia (seção 2) com uma análise comparativa entre as regras atuais, a proposta de reforma original e o substitutivo apresentado na Comissão Especial da Câmara dos Deputados. Em seguida, são apresentadas as medidas de governança do auxílio-doença e da aposentadoria por invalidez, incluindo os incentivos à intensificação de perícias, introduzidos pela Medida Provisória (MP) nº 739, de julho de 2016. Esta medida perdeu a validade no final de 2016, e o governo federal voltou a apresentar uma nova MP (no 767/2017), que posteriormente foi convertida na Lei no 13.457, de 26 de junho de 2017. Também merece destaque a decisão do Supremo Tribunal Federal (STF) de não reconhecer validade jurídica ao instituto da desaposentação, por meio do qual seria permitido aumentar o valor do benefício com base nas contribuições realizadas após a aposentadoria.

A seçáo 3 deste capítulo é voltada para o acompanhamento da política previdenciária, tendo em perspectiva a expansão dos principais indicadores de formalidade trabalhista e previdenciária observada particularmente entre 2002 
e 2013. De acordo com a Pesquisa Nacional por Amostra de Domicílio (Pnad) de 2015, 72,5\% dos trabalhadores ocupados estavam protegidos pela Previdência Social - ou seja, contribuem para algum regime previdenciário público ou são segurados especiais ou, embora não contribuam e não pertençam ao regime especial rural, já são beneficiários da Previdência ou da assistência social. O crescimento constante dessas taxas desde o início da década 2000, como se verá adiante, é reflexo da dinâmica econômica positiva no período e de medidas voltadas à contribuição autônoma.

Apesar desses números positivos, o desafio do equilíbrio das contas previdenciárias é também analisado na seção 3, que examina a pressão do envelhecimento acelerado da população, especialmente no longo prazo. Como não poderia deixar de ser, analisa-se a participação dos diferentes regimes previdenciários no resultado geral. Essa desagregação é imprescindível, principalmente se levarmos em consideração que, em termos relativos e absolutos, o resultado previdenciário brasileiro se encontra bastante influenciado por desequilíbrios expressivos, financeiros e atuariais, em regimes próprios com um volume de beneficiários (diretos e indiretos) bem menos numeroso que o quantitativo registrado para o Regime Geral de Previdência Social (RGPS). Ao final, é apresentada uma comparação do Brasil em termos de despesa previdenciária e taxa de dependência dos idosos com países que possuem cobertura elevada e que já enfrentaram a transição demográfica que o Brasil deverá encarar nas próximas décadas.

\section{FATOS RELEVANTES}

\subsection{PEC no 287/2016: proposta de reforma da Previdência Social}

O governo federal apresentou uma proposta de reforma da Previdência Social em dezembro de 2016, a PEC no 287/2016. Esta PEC altera tanto as regras RGPS quanto as dos Regimes Próprios de Previdência Social dos Servidores Públicos (RPPS). O relatório apresentado na Comissão Especial, em maio de 2017, traz mudanças em alguns pontos, a seguir apresentados, comparativamente à proposta original.

No caso dos RPPS, a proposta inicial era o aumento da idade mínima de aposentadoria, bem como a convergência das regras do RPPS com as do RGPS. No texto original, da PEC no 287/2016, propunha-se a mesma regra para os dois regimes, 65 anos de idade e 25 anos de contribuição, mantida a condicionalidade de tempo mínimo de dez anos de efetivo exercício no serviço público e cinco anos no cargo efetivo em que se dará a aposentadoria, no caso dos regimes próprios. A Comissão da Câmara, contudo, acabou reduzindo a idade das mulheres urbanas e servidoras públicas para 62 anos, dos homens rurais para 60 anos (que já é o parâmetro atual) e das mulheres rurais para 57 anos (contra os 55 anos atuais). A carência contributiva foi reduzida apenas para os trabalhadores rurais do RGPS, 
que seguiriam com o requisito mínimo atual ( 15 anos), mas passariam a contribuir de forma individualizada e não por meio de uma alíquota sobre a comercialização da produção como ocorre atualmente. Posteriormente, emenda aglutinativa apresentada no final de 2017 excluiu da proposta de reforma as mudanças relativas à previdência rural, ao Benefício de Prestação Continuada (BPC) e manteve o tempo mínimo de contribuição para o RGPS em quinze anos.

Ademais, também haveria mudança na fórmula de cálculo das aposentadorias, tanto a voluntária quanto a por invalidez ou incapacidade permanente. $\mathrm{Na}$ proposta original, os proventos de aposentadoria corresponderiam a 51\% da média das remuneraçóes e dos salários de contribuição utilizados como base para as contribuiçóes, acrescidos de 1 ponto percentual (p.p.) para cada ano de contribuição adicional. Mas a Câmara alterou para uma regra que iniciava em $70 \%$ para 25 anos de contribuição e $1,5 \%, 2 \%$ ou $2,5 \%$ para os anos adicionais de contribuição, chegando a 100\% com quarenta anos de contribuição. No caso da aposentadoria por invalidez no RPPS, a regra geral atual é que o cálculo deve ser feito de forma proporcional ao tempo de contribuição, exceto se decorrente de acidente em serviço, moléstia profissional ou doença grave, contagiosa ou incurável, na forma da lei. Com a reforma, a aposentadoria por invalidez seguiria a mesma regra de cálculo proposta, sendo que a exceção para garantir 100\% da média das remuneraçóes se tornava exclusiva para os casos de incapacidade permanente decorrentes de acidentes de trabalho ou doença profissional.

Também no que se refere ao valor dos benefícios de aposentadoria e pensão dos RPPS, a proposta estabelece que os proventos de aposentadoria dos RPPS não poderiam ser inferiores ao limite mínimo ou superiores ao limite máximo estabelecidos para o RGPS, o que na prática implica o mesmo piso e o mesmo teto tanto para os RPPS quanto para o RGPS. Haveria obrigatoriedade de instituição da previdência complementar.

Também haveria alteraçóes nas chamadas aposentadorias especiais dos RPPS. Em primeiro lugar, atualmente há permissão para adoção de critérios diferenciados de aposentadoria para pessoas com deficiência, atividades de risco e que sejam exercidas sob condiçóes especiais que prejudiquem a saúde ou a integridade física. Na proposta original, permaneceriam a possibilidade de adoção de critérios diferenciados para pessoas com deficiência e atividades que sejam exercidas sob condiçóes especiais que prejudiquem a saúde ou a integridade física, sendo revogada a aposentadoria especial para servidores que exerçam atividades de risco.

As propostas de mudanças na aposentadoria especial também seriam no sentido de endurecimento das regras, tendo em vista que foi estabelecido que a redução da idade decorrente da aposentadoria especial deveria ser de no máximo dez anos, em relação à regra geral (65 anos), e a diminuição no tempo de contribuição de no 
máximo cinco anos. Também foi proposto o fim da aposentadoria especial para os professores do RPPS, tendo em vista que a PEC propóe a revogação do parágrafo 5ํ, do art. 40, da Constituição Federal de 1988 (CF/1988), que garantia o direito de redução de cinco anos na idade e de tempo de contribuiçáo para professores exclusivamente na educação infantil e nos ensinos fundamental e médio. Mas a Câmara acabou reduzindo a idade mínima para 60 anos de idade para professores e 55 anos de idade para vários grupos de policiais, como polícia federal, polícia rodoviária federal e polícia civil.

As pensōes por morte tiveram importantes propostas de modificaçóes. Em primeiro lugar, a $\mathrm{PEC} \mathrm{no} 287 / 2016$ proíbe a acumulação de pensão com aposentadoria náo apenas no âmbito dos RPPS, mas também entre regimes, ou seja, entre RPPS e RGPS. A fórmula de cálculo das pensóes do RPPS, que atualmente é de $100 \%$ até o teto do RGPS mais $70 \%$ da parcela que excedesse o teto, passaria para $50 \%$, acrescido de $10 \%$ por cada dependente e sem garantia do salário mínimo. Contudo, a Comissão da Câmara propôs a manutenção do piso do salário mínimo e a possibilidade de acumulação de aposentadoria e pensão por morte até o teto de 2 salários mínimos (SMs).

Em relação ao teto do valor dos benefícios, atualmente há a possibilidade de estabelecer o teto do RGPS como teto do RPPS, desde que instituída a previdência complementar, algo que não foi executado pela grande maioria dos regimes próprios. A proposta é tornar obrigatório que o teto do RPPS seja o mesmo do RGPS depois da instituiçáo da previdência complementar. Os entes federativos que tenham RPPS e não tenham previdência complementar e entidade gestora única, de acordo com o art. 15 da PEC no 287/2016, teriam dois anos para cumprir essas obrigaçóes. Foi mantido o chamado abono de permanência para aqueles servidores que têm condiçóes de se aposentar, mas decidem permanecer em atividade.

As propostas de mudanças apresentadas pela $\mathrm{PEC} \mathrm{n}$ 287/2016 são profundas também no âmbito do RGPS, ainda que suavizadas pela Comissão Especial da Câmara dos Deputados. Um ajuste é a eliminação da chamada aposentadoria por tempo de contribuição (ATC) sem exigência de idade mínima, que gera aposentadorias precoces, ${ }^{1}$ bem como a unificação das regras de forma a haver condicionalidades conjuntas em termos de idade e tempo de contribuição. Deixaria de existir a possibilidade de se aposentar com 35 anos de contribuição para homens e trinta anos para mulheres e, de forma similar à regra proposta para os RPPS,

\footnotetext{
1. A idade média de aposentadoria por tempo de contribuição ( 54,73 anos, em 2015, para ambos os sexos) é significativamente inferior à própria idade de referência para a identificação de idosos no país - conforme o critério previsto no Estatuto do Idoso (60 anos), o qual eventualmente também deverá ser adaptado em função da evolução demográfica - e se mostra crescentemente incompatível com a evolução da expectativa de vida do brasileiro, gerando pagamentos por períodos mais prolongados que o suportado pelo RGPS (ou seja, gerando desequilíbrios no confronto do valor presente dos fluxos de benefícios e contribuições).
} 
a condicionalidade para se aposentar passa para 65 anos de idade para homens e 62 anos para mulheres e 25 anos de contribuição (excetuando-se trabalhadores rurais, professores e alguns grupos de policiais). Com esta proposta: $i$ ) seria eliminada a aposentadoria por tempo de contribuição sem idade mínima; ii) seria ampliado o período mínimo de contribuição, no caso da aposentadoria por idade, de quinze para 25 anos de contribuição; e iii) seria aumentada a condicionalidade da aposentadoria por idade de 60 para 62 anos de idade para as mulheres urbanas, e de 55 para 57 anos para as mulheres rurais. De forma similar à regra dos RPPS e dentro da lógica de convergência dos regimes, a idade de aposentadoria passaria a ser vinculada com o crescimento da expectativa de vida. Posteriormente, emenda aglutinativa apresentada no final de 2017 manteve as regras para a previdência rural, o BPC e o tempo mínimo de contribuição de quinze anos para o RGPS.

Também haveria alteraçôes na regra de cálculo, que no caso do RGPS deixa de ser a média dos $80 \%$ maiores salários de contribuição com incidência do fator previdenciário para aposentadoria por tempo de contribuição, para $70 \%$ no caso de 25 anos de contribuiçáo e $1,5 \%, 2 \%$ ou $2,5 \%$ para os anos adicionais de contribuição, chegando a $100 \%$ com quarenta anos de contribuição - nos termos do substitutivo apresentado na Comissão da Câmara, já mencionado.

Nos RPPS, a integralidade e a paridade seriam eliminadas para os servidores que, mesmo tendo entrado antes de 2004 no serviço público, tivessem, na data da reforma, menos de 50 anos de idade, para homens, e 45 anos de idade, para mulheres. A Câmara também suavizou a medida, garantindo a integralidade e a paridade para todos que entraram no serviço público antes de 2004, desde que se aposentassem aos 65 anos de idade, para homens, e 62 anos de idade, para mulheres.

A reforma traria mudanças específicas para a previdência rural. Atualmente, por determinação constitucional, os chamados segurados especiais, que exercem atividade agropecuária em regime de economia familiar, têm a contribuição vinculada à comercialização da produção, com sub-rogação do recolhimento da contribuição correspondente ao adquirente do produto. Apesar da previsão legal da contribuição, como na legislação infraconstitucional não se exige a comprovação da contribuição dos segurados especiais, mas apenas o exercício da atividade, acaba prevalecendo um esquema com pouca contribuição no setor rural do RGPS, em especial, quando comparado com o volume de pagamento de benefícios.

Nos termos da PEC no 287/2016, a contribuição não seria obrigatoriamente vinculada à comercialização da produção e destinada à proteção do grupo familiar, mas seria individualizada com alíquota favorecida sobre o piso previdenciário do RGPS, nos termos e prazos definidos em lei. A medida visa fortalecer o caráter contributivo da previdência rural, atrelando a concessão de benefícios à contribuição previdenciária, mesmo que ainda subsidiada. A regulamentação posterior da reforma, 
via lei, deveria ser editada em até doze meses a contar da data de promulgação da reforma. Até a instituição desta nova contribuição para o setor rural, seria mantido o critério de aplicação de uma alíquota sobre o resultado da comercialização da produção, nos termos da legislação vigente.

Há uma proposta de continuidade de ajuste nas regras de pensão por morte, que sofreram importantes alteraçôes em 2015, como a mudança no cálculo do valor de $100 \%$ da aposentadoria ou da aposentadoria por invalidez que o instituidor teria direito para $50 \%$ mais $10 \%$ por dependente, que chegou a ser contemplada na Medida Provisória no 664/2014, mas que foi rejeitada pelo Congresso, bem como o fim da reversão das cotas.

De forma similar aos RPPS, haveria um endurecimento das regras de aposentadoria especial, com limites de redução de idade (dez anos) e de tempo de contribuição (cinco anos). No caso do RGPS, haveria a vedação de aposentadoria especial por categoria profissional ou ocupação.

O Benefício de Prestação Continuada (BPC) da Lei Orgânica da Assistência Social (Loas), embora seja um benefício assistencial destinado a idosos e pessoas com deficiência em situação de pobreza, na prática, trata-se de uma aposentadoria de caráter não contributivo. A PEC no 287/2016 propôs o aumento da idade de 65 para 70 anos para os idosos, além da vinculação com o crescimento da expectativa de vida, bem como o fim da adoção do salário mínimo como referência do valor do benefício. O incremento de 65 para 70 anos ocorreria ao ritmo de um ano a cada dois anos, ou seja, seria uma mudança que duraria dez anos e o valor permaneceria atrelado ao salário mínimo até a promulgação de lei que regulamentasse o novo valor e a fórmula de reajuste do benefício. O texto substitutivo manteve a vinculação com a evolução da expectativa de sobrevida, mas reduziu a idade máxima inicial de 70 anos de idade para 68 anos, referência possivelmente ainda elevada para este grupo.

A PEC no 287/2016 não tratou das regras de aposentadoria e pensão dos militares do governo federal, nem de policiais militares e bombeiros dos estados.

Do ponto de vista de alteraçóes nas renúncias, a PEC no 287/2016 propóe a eliminação da isenção de contribuições previdenciárias que sejam incidentes sobre receitas substitutivas da folha de salários, ou seja, na prática, propóe o fim da renúncia previdenciária sobre as exportaçóes rurais no âmbito do RGPS. 
QUADRO 1

Resumo das regras atuais, propostas da PEC n 287 e do substitutivo proposto pela Comissão Especial da Câmara dos Deputados

\begin{tabular}{|c|c|c|}
\hline \multicolumn{3}{|c|}{ RGPS } \\
\hline Regra atual & PEC no 287/2016 & $\begin{array}{l}\text { Substitutivo da Comissão Especial da Câmara } \\
\text { dos Deputados }\end{array}$ \\
\hline $\begin{array}{l}\text { Aposentadoria por tempo de contri- } \\
\text { buição - } 35 \text { anos de contribuição para } \\
\text { homens e } 30 \text { anos para mulheres sem } \\
\text { idade mínima. }\end{array}$ & $\begin{array}{l}\text { Fim gradual da aposentadoria por tempo } \\
\text { de contribuição. Nova regra de } 65 \text { anos } \\
\text { de idade e } 25 \text { anos de contribuição. Para } \\
\text { homens e mulheres acima de } 50 \text { e } 45 \\
\text { anos, haveria um pedágio de } 50 \% \text { do } \\
\text { tempo de contribuição que faltava. }\end{array}$ & $\begin{array}{l}\text { Altera-se a regra de transição eliminando o corte } \\
\text { de } 50 \text { e } 45 \text { anos, abrindo a possibilidade de } \\
\text { pedágio de } 30 \% \text { sobre o que faltava para } 35 / 30 \\
\text { anos de contribuição para todos. Contudo, estabe- } \\
\text { lece idade mínima progressiva, que começaria em } \\
55 \text { anos para homens e } 53 \text { anos para mulheres e } \\
\text { subiria de forma gradual até } 65 \text { e } 62 \text { anos. }\end{array}$ \\
\hline $\begin{array}{l}\text { Aposentadoria por idade urbana - } 65 \\
\text { anos para homens e } 60 \text { anos para } \\
\text { mulheres com pelo menos } 15 \text { anos de } \\
\text { contribuição. }\end{array}$ & $\begin{array}{l}\text { Idade de } 65 \text { anos tanto para homens } \\
\text { quanto para mulheres e } 25 \text { anos de } \\
\text { contribuição para todos (com regra de } \\
\text { transiç̧ão). }\end{array}$ & $\begin{array}{l}\text { Idade de } 65 \text { anos para homens e } 62 \text { anos para } \\
\text { mulheres com } 25 \text { anos de contribuição (com } \\
\text { regra de transição). }\end{array}$ \\
\hline $\begin{array}{l}\text { Aposentadoria por idade rural - } 60 \\
\text { anos para homens e } 55 \text { anos de idade } \\
\text { para mulheres com comprovação do } \\
\text { exercício de atividade rural de pelo } \\
\text { menos quinze anos. }\end{array}$ & $\begin{array}{l}\text { Sessenta e cinco anos para homens e } \\
\text { mulheres e regime passaria a exigir con- } \\
\text { tribuição individualizada, embora com } \\
\text { previsão de alíquota subsidiada a ser } \\
\text { regulamentada por lei. Subida gradual de } \\
\text { quinze para } 25 \text { anos de contribuição. }\end{array}$ & $\begin{array}{l}\text { Sessenta anos para homens, que já é o } \\
\text { parâmetro atual, e } 57 \text { anos para mulheres com } \\
\text { contribuição individualizada, mas especial ou } \\
\text { subsidiada. Quinze anos de contribuição. }\end{array}$ \\
\hline $\begin{array}{l}\text { Pensão por morte - cálculo como } 100 \% \\
\text { da aposentadoria do instituidor ou da } \\
\text { que teria direito independentemente do } \\
\text { número de dependentes, sem restrição } \\
\text { para acumulação com aposentadoria e } \\
\text { com garantia do salário mínimo. }\end{array}$ & $\begin{array}{l}\text { PEC - pensão calculada como } 50 \% \text { mais } \\
10 \% \text { por dependente, sem garantia do } \\
\text { salário mínimo e vedada acumula- } \\
\text { ção com aposentadoria não apenas } \\
\text { intraregime (RGPS) mas também entre } \\
\text { regimes (RGPS e RPPS). Fim da reversão } \\
\text { das cotas. }\end{array}$ & $\begin{array}{l}\text { Propõe a manutenção da garantia do salário } \\
\text { mínimo, mas estabelece a regra de } 50 \% \text { mais } \\
10 \% \text { por dependente. Permite a acumulação } \\
\text { de pensão com aposentadoria, mas até o teto } \\
\text { de dois salários mínimos. }\end{array}$ \\
\hline $\begin{array}{l}\text { Regra de cálculo de } 70 \% \text { mais } 1 \% \text { para } \\
\text { aposentadoria por idade e média versus } \\
\text { fator previdenciário para ATC se não } \\
\text { atendesse à regra } 85 / 95 \text { progressiva. }\end{array}$ & $\begin{array}{l}\text { Regra de cálculo de } 51 \% \text { mais } 1 \% \text { por } \\
\text { ano de contribuição, aplicada à média dos } \\
\text { salários de contribuição com composição } \\
\text { definida em lei, mas com garantia de } \\
\text { salário mínimo para as aposentadorias. }\end{array}$ & $\begin{array}{l}\text { Setenta por cento para } 25 \text { anos de contribuição, } \\
\text { mais 1,5\%,2\% ou 2,5\% por ano de contribui- } \\
\text { ção, atingindo } 100 \% \text { com quarenta anos de } \\
\text { contribuição. Regra aplicada à média dos salários } \\
\text { de contribuição. }\end{array}$ \\
\hline \multicolumn{3}{|c|}{ RPPS } \\
\hline Regra atual & PEC no 287/2016 & Substitutivo da Comissão Especial da Câmara \\
\hline $\begin{array}{l}\text { Aposentadoria de homens com } 60 \\
\text { anos de idade e } 35 \text { anos de contribui- } \\
\text { ção e mulheres com } 55 \text { anos de idade } \\
\text { e } 30 \text { anos de contribuiç̧ão. }\end{array}$ & $\begin{array}{l}\text { Aposentadoria de } 65 \text { anos para homens } \\
\text { e mulheres com } 25 \text { anos de contribuição. }\end{array}$ & $\begin{array}{l}\text { Sessenta e cinco anos para homens e } 62 \text { anos } \\
\text { para mulheres com } 25 \text { anos de contribuição. }\end{array}$ \\
\hline $\begin{array}{l}\text { Aposentadorias especiais para } \\
\text { professores, agentes nocivos à saúde e } \\
\text { atividades de risco. }\end{array}$ & $\begin{array}{l}\text { Fim da aposentadoria especial em ativi- } \\
\text { dades de risco e para professores. }\end{array}$ & $\begin{array}{l}\text { Idade mínima de } 60 \text { anos de idade para } \\
\text { professores e } 55 \text { anos para diversos grupos } \\
\text { de policiais. }\end{array}$ \\
\hline $\begin{array}{l}\text { Paridade e integralidade para pessoas } \\
\text { que entraram no serviço público até } \\
\text { 2003. Instituição da previdência com- } \\
\text { plementar facultativa para os RPPS. }\end{array}$ & $\begin{array}{l}\text { Paridade e integralidade seria mantida } \\
\text { para quem entrou até } 2003 \text { se tinha } \\
\text { mais de } 50 \text { anos de idade no caso de } \\
\text { homens e } 45 \text { anos no caso das mulheres. } \\
\text { Instituição da previdência complementar } \\
\text { obrigatória para todos os RPPS. }\end{array}$ & $\begin{array}{l}\text { Manteve a paridade e integralidade para } \\
\text { pessoas que entraram nos RPPS até 2003, } \\
\text { desde que se aposentassem aos } 65 \text { anos de } \\
\text { idade para homens e } 62 \text { anos de idade para } \\
\text { mulheres. Instituição da previdência comple- } \\
\text { mentar obrigatória para todos os RPPS. }\end{array}$ \\
\hline \multicolumn{3}{|c|}{ BPC/Loas } \\
\hline Regra atual & PEC no 287/2016 & Substitutivo da Comissão Especial da Câmara \\
\hline $\begin{array}{l}\text { Benefício não contributivo para idosos } \\
\text { de } 65 \text { anos ou mais de idade e com } \\
\text { deficiência vinculado ao salário mínimo } \\
\text { para pessoas em situação de pobreza. }\end{array}$ & $\begin{array}{l}\text { Idade de acesso cresceria de forma } \\
\text { gradual de } 65 \text { para } 70 \text { anos de idade e } \\
\text { haveria desvinculação do salário mínimo. }\end{array}$ & $\begin{array}{l}\text { Manteve a vinculação com salário mínimo e } \\
\text { o crescimento da idade seria de } 65 \text { para } 68 \\
\text { anos de idade. }\end{array}$ \\
\hline
\end{tabular}

Fontes: PEC no 287/2016 e substitutivo da Comissão Especial da Câmara.

Elaboração dos autores. 
Além das propostas de alteração das regras permanentes, a PEC no 287/2016 estabeleceu uma regra de transição bastante simples para os RPPS, pela qual homens com menos de 50 anos de idade e mulheres com menos de 45 anos na data de promulgação da emenda já seriam submetidos à regra nova de 65 anos de idade e 25 anos de contribuição. Aqueles com idade superior a esses limites poderiam se aposentar com 60 anos de idade para os homens e 55 anos de idade para as mulheres, com a exigência de um período adicional de contribuição de $50 \%$ do tempo que, na data de promulgação da emenda, faltaria para completar 35 anos de contribuição no caso dos homens e trinta anos de contribuição no caso das mulheres. Professores teriam regra similar de transição, mas os requisitos de idade e tempo de contribuição são reduzidos em cinco anos. Todavia, a Câmara acabou criando uma regra de transição bem mais complicada, que abre o pedágio de $30 \%$ para todos, mas estabelece idades mínimas progressivas que começam, no caso do RPPS, em 60/66 anos, para homens e mulheres, e sobem progressivamente (um ano a cada dois anos) para 65/62 anos.

De forma geral, a PEC no 287/2016 respeita os direitos adquiridos e não promove nenhuma alteraçâo para aqueles que já estâo aposentados. Ademais, na proposta existe a previsão de que fica assegurada a concessão de aposentadoria ao servidor público que tenham cumprido todos os requisitos para obtenção desses benefícios até a data de promulgação da emenda que irá decorrer da PEC no $287 / 2016$. O mesmo se aplica à pensáo por morte aos dependentes de servidor público nas mesmas condiçôes.

No caso de pessoas com mandato eletivo, a proposta é que, de imediato, aos titulares de novos mandatos eletivos que forem diplomados após a promulgação da emenda, se apliquem as regras do RGPS. No entanto, caberá a cada ente federativo, ou seja, União, estados, Distrito Federal e municípios, dispor sobre as regras de transição para os diplomados anteriormente à data de promulgação da emenda constitucional.

As regras de transição também se aplicam ao RGPS, com os mesmos critérios do RPPS. Ou seja, na proposta original, homens com idade igual ou superior a 50 anos, e mulheres com idade de 45 anos ou mais, também poderiam se aposentar pelas regras atuais da aposentadoria por idade e tempo de contribuição, acrescidos de um período adicional de contribuição equivalente a 50\% do tempo que, na data de promulgaçáo da emenda, faltaria para atingir o tempo de contribuição exigido pelas regras atuais ( 35 anos de contribuição para homens e trinta anos para mulheres no caso de ATC e, para a aposentadoria por idade, para o tempo que faltava para alcançar o mínimo de quinze anos de contribuição), mas respeitadas as idades mínimas de 65/60 anos (homens/mulheres) para os trabalhadores urbanos. Mas, como já exposto no caso dos RPPS, a Câmara alterou a regra de transição, 
eliminando o corte de 50 e 45 anos e abrindo a possibilidade de pedágio de 30\% sobre que faltava para 35/30 anos de contribuição para todos. Além disso, estabeleceu idade mínima progressiva que começaria em 55 anos para homens e 53 anos para mulheres, que subiriam de forma gradual até 65 e 62 anos.

Até o presente momento, ${ }^{2}$ existe incerteza em qual será o resultado final da PEC no ${ }^{2}$ 87/2016 e do substitutivo aprovado na Câmara, inclusive pela paralisaçáo do andamento da reforma no período de maio até meados de outubro de 2017 , em função das instabilidades políticas que marcaram o cenário brasileiro. $\mathrm{Na}$ atual conjuntura, existe a possibilidade de que a proposta sofra novas alteraçóes para garantir sua aprovação, embora com defesa de pontos fundamentais, como idade mínima com regra de transição e equiparação entre previdência dos servidores públicos e trabalhadores do setor privado. De qualquer forma, existe incerteza em qual será o resultado final da tentativa de reforma da previdência que foi iniciada com a apresentação da PEC no 287/2016. Como colocado anteriormente, no final de 2017, foi apresentada emenda aglutinativa que excluía da proposta de reforma as mudanças na previdência rural, no BPC e mantinha o tempo mínimo de contribuição no RGPS em quinze anos.

\subsection{Medidas Provisórias nos 739/2016 e 797/2017 e Lei no 13.457/2017: revisão dos benefícios por incapacidade}

Com o objetivo de conter a expansão das despesas com benefícios por incapacidade (auxílios-doença e aposentadoria por invalidez), o governo federal encaminhou ao Congresso Nacional a Medida Provisória no 739, de 7 de julho de 2016. $\mathrm{Na}$ exposição de motivos da referida $\mathrm{MP}$, foi argumentado que, do então estoque total de 1,6 milhão de beneficiários do auxílio-doença, aproximadamente 839 mil pessoas estariam recebendo o benefício há mais de dois anos e não teriam passado por perícia médica do Instituto Nacional do Seguro Social (INSS) para constatar, se, de fato, a incapacidade laborativa permanecia.

O texto da MP no 739/2016 faz referência ao art. 101 da Lei no 8.213/1991, no qual se estabelece que o segurado em gozo de auxílio-doença ou aposentadoria por invalidez e o pensionista inválido estão obrigados, sob pena de suspensão do benefício, a submeter-se a exame médico a cargo da Previdência Social, processo de reabilitação profissional por ela prescrito e custeado e tratamento dispensado gratuitamente, exceto o cirúrgico e a transfusão de sangue, que são facultativos. A MP tampouco desconsidera as exceçóes a essa regra, mantendo desobrigados de seu cumprimento os aposentados por invalidez e os pensionistas inválidos que completarem 60 anos de idade, salvo nas situaçôes específicas que já estavam previstas em lei.

2. Versão final do texto escrita em 15 de janeiro de 2018. 
A MP também determinou que, sempre que possível, o ato (judicial ou administrativo) de concessão ou de reativação de auxílio-doença deveria fixar o prazo estimado para a duração do benefício. Indo além, o texto estabelece que, na ausência de um prazo pré-estabelecido, o benefício seria cessado após o prazo de 120 dias, contado da data de concessão ou reativação, exceto se o segurado viesse a requerer sua prorrogação junto ao INSS.

Argumenta-se ainda, no caso das concessôes judiciais, o risco de violação da garantia constitucional da coisa julgada. ${ }^{3}$ Não parece razoável assumir que um benefício concedido judicialmente seja vitalício, dado que nenhum benefício por incapacidade o é (salvo em situaçôes bastante específicas, legalmente previstas), motivo pelo qual este deveria também ser sujeito a revisóes, tanto quanto aqueles concedidos administrativamente. Isso, não apenas porque um juiz, como qualquer agente público, está sujeito a equívocos, mas, principalmente, porque as circunstâncias e condiçóes que motivaram sua decisão podem ter se alterado, tornando indevida sua manutenção.

A revisão desse estoque antigo (com duração superior a dois anos), por assim dizer, de benefícios por incapacidade também foi objeto específico da MP no 739/2016, que previu medidas de intensificação da atividade pericial (mediante mutirôes e incentivos financeiros adicionais para a realização de perícias), em uma tentativa de evitar que esse esforço afetasse ainda mais a demanda por perícias iniciais, de reconhecimento inicial de direito. A MP instituiu, por até 24 meses, o Bônus Especial de Desempenho Institucional por Perícia Médica em Benefícios por Incapacidade (Besp-PMBI), que consistiria no pagamento de $\mathrm{R} \$ 60$ por perícia médica, desde que esta fosse realizada em relação a benefícios por incapacidade mantidos (sem perícia pelo INSS) há mais de dois anos, e que representasse acréscimo real à capacidade operacional ordinária de realizaçáo de perícias médicas pelo médico perito e pela respectiva agência da Previdência Social - ou seja, em período extraordinário em relação à jornada regular de trabalho do médico perito. ${ }^{4}$

A MP no 739/2016 também alterou o art. 62, que determinava que o segurado em gozo de auxílio-doença, insusceptível de recuperação para sua atividade habitual, deveria submeter-se a processo de reabilitação profissional para o exercício de outra atividade. $\mathrm{O}$ referido artigo ainda estabelecia que o benefício concedido não seria cessado até que o indivíduo afastado fosse dado como habilitado para o desempenho de nova atividade que lhe garantisse a subsistência ou, quando considerado não

3. A coisa julgada está relacionada com a sentença judicial e com a segurança jurídica das decisões judiciais, sendo a mesma irrecorrível, ou seja, não admitindo mais a interposição de qualquer recurso.

4. 0 bônus não seria incorporado aos vencimentos, à remuneração ou aos proventos das aposentadorias e das pensões, e não serviria de base de cálculo para benefícios ou vantagens, nem tampouco integraria a base de contribuição previdenciária do servidor. 
recuperável, fosse aposentado por invalidez. A mudança no texto é sutil, dado que tal entendimento se manteve, simplesmente, tornando mais enfática uma obrigatoriedade que já era imposta anteriormente. Sobre este ponto, uma vez mais, resta avaliar se o INSS reúne as condições financeiras, operacionais e logísticas de cumprir com a sua parte nesse compromisso, visto que historicamente os programas de reabilitação profissional da instituição se mostraram insuficientes para fazer frente à necessidade dos segurados.

Por fim, a Medida Provisória nº 739/2016 revogou o parágrafo único contido no art. 24 da Lei no 8.213/1991, que permitia o aproveitamento das contribuiçóes previdenciárias anteriores à perda da qualidade de segurado, ${ }^{5}$ desde que, após a retomada das contribuiçóes ao RGPS, obtivesse ao menos um terço dos recolhimentos mensais necessários para o cumprimento da carência exigida para a concessão do benefício previdenciário requerido. Ao mesmo tempo, incluiu-se um parágrafo único no art. 27, estabelecendo que, no caso da perda dessa qualidade, para efeito de carência para a concessão dos benefícios de auxílio-doença, salário-maternidade e aposentadoria por invalidez, o segurado deveria acumular, a partir da retomada das contribuiçóes, a totalidade das carências mínimas exigidas para estas espécies, nos termos dos incisos I e III do caput do art. 25 da Lei no 8.213/1991.

Contudo, a MP perdeu a validade em 4 de novembro de 2016, já que aparentemente não houve consenso para sua conversão em lei. Para substituí-la, o governo federal apresentou o Projeto de Lei (PL) no 6.427/2016, com igual teor, que foi distribuído à Comissão de Constituição e Justiça e de Cidadania (CCJC), à Comissão de Finanças e Tributação (CFT), à Comissão de Trabalho, de Administração e de Serviço Público (CTASP) e à Comissão de Seguridade Social e Família (CSSF). O PL recebeu parecer pela aprovação na CSSF ainda em 2016 (com rejeição das nove emendas apresentadas) e na CTASP em setembro de 2017 (com aprovação das nove emendas), mas foi retirado de pauta desta última sete dias depois, por requerimento de parlamentares.

No começo de 2017, o governo voltou à tona com a revisão dos benefícios por incapacidade por meio da MP no $797 / 2017$, posteriormente convertida na Lei no 13.457/2017. De forma similar ao que estava estabelecido na MP no 739/2016, sempre que possível, o ato de concessão ou de reativação de auxílio-doença, judicial ou administrativo, deverá fixar o prazo estimado para a duração do benefício. $\mathrm{Na}$ ausência de fixação de prazo, o benefício deve ser cessado após o prazo de 120 dias, contado da data de concessão ou de reativação do auxílio-doença, exceto se o segurado requerer a sua prorrogação. Também foi reinstituído o Besp-PMBI.

5. A qualidade de segurado é a condição atribuída a todo indivíduo filiado ao RGPS e que faça recolhimentos mensais a título de contribuiç̧ão previdenciária. A legislação previdenciária determina que, em situaçõ̃es específicas, mesmo na falta de recolhimentos regulares mensais, os segurados possam manter esta qualidade, denominada período de graça. 
Houve mudança em relação ao proposto na MP no 739/2016: no caso de perda da qualidade de segurado, o segurado deverá contar, a partir da nova filiaçáo, com metade dos períodos de carência previstos para os benefícios de auxílio-doença, aposentadoria por invalidez e salário-maternidade.

\subsection{Decisão do Supremo Tribunal Federal: desaposentação}

Em 2016, um dos pontos de destaque, em matéria previdenciária, foi a decisão do STF na apreciação do Tema 503 de repercussão geral, ou melhor, no julgamento do Recurso Extraordinário (RE) 661256, relativo à "conversão de aposentadoria proporcional em aposentadoria integral por meio do instituto da desaposentação" (STF, 2016). Em síntese, no RE 661256 se discutiu, à luz do art. 5oc caput, inciso XXXVI; arts. 40, 194 e 195, caput e $\$$ 5; e art. 201, $\$ 1$ 을 da Constituição Federal, a possibilidade, ou não, de reconhecer validade jurídica ao instituto da desaposentação, por meio do qual seria permitida a conversão da aposentadoria proporcional em aposentadoria integral, pela renúncia ao primeiro benefício e cômputo das contribuiçôes recolhidas posteriormente à primeira jubilação. $\mathrm{Na}$ prática, tratava-se de demanda de trocar uma aposentadoria de menor por outro de maior valor a partir da consideração de contribuições realizadas após o primeiro benefício de aposentadoria.

Trata-se da situação concreta em que um segurado continuou a trabalhar depois de aposentado, vertendo contribuiçóes ao RGPS, de modo que, passado algum tempo, a contabilização deste período adicional de cotizaçâo - acompanhado do natural acúmulo de anos adicionais de vida, relevantes para o cálculo do fator previdenciário - poderia resultar em benefício mais vantajoso, de maior valor monetário. Este quadro suscitava inúmeros pedidos de renúncia à aposentadoria anterior (original), para o posterior requerimento de outro benefício do mesmo grupo de espécie (aposentadorias), com base em cálculo atualizado pela nova idade e pelo tempo de contribuição suplementar. Normalmente (ainda que não somente), estas situaçôes estiveram associadas a aposentadorias classificadas como precoces, concedidas para segurados com plena capacidade laborativa. Por estar fortemente associada às aposentadorias precoces, a desaposentação seria um prêmio para estas, com efeitos negativos sobre a sustentabilidade do RGPS e um grande desestímulo a postergação da aposentadoria.

A aposentadoria voluntária precoce, normalmente onerosa para regimes de repartição simples - caso não haja ao menos alguma penalidade financeira, em termos de taxa de reposição, por exemplo -, ocorre no RGPS com frequência, dada a possibilidade de aposentadorias por tempo de contribuição, sem exigência de idade mínima. No Brasil, esse fenômeno apenas é (tentativamente) desestimulado pelas regras de cálculo do salário de benefício - em particular, pelo fator previdenciário, bastante descaracterizado pela recente vigência da chamada fórmula 
85/95 Progressiva ${ }^{6}$ - e pelo fato de que o aposentado que permanecer ou retornar ao mercado de trabalho formal continua filiado ao RGPS, o que gera o dever de contribuir, sem contrapartida no âmbito do próprio regime. A lógica inerente a esse modelo deriva do entendimento de que os recolhimentos devidos pelos aposentados ocupados seriam, em geral (entre os trabalhadores formais), vertidos ao RGPS, mas por trabalhadores ainda náo protegidos pelo recebimento de aposentadorias. A isenção previdenciária dos aposentados ocupados configuraria então uma piora significativa no equilíbrio entre receitas e despesas do sistema, bem como eliminaria os limitados desincentivos existentes no país para a acumulação de rendimentos laborais e previdenciários.

A desaposentação implicaria riscos semelhantes e tenderia a ser bastante danosa, notadamente se não viesse acompanhada da obrigatoriedade de devoluçáo das parcelas já recebidas. ${ }^{7} \mathrm{O}$ entendimento de que o aposentado poderia renunciar ao seu benefício, para recebimento de outro, sem a exigência de que os valores já recebidos fossem devolvidos, iria de encontro à Constituição Federal - que em seu art. 201 estabelece o caráter contributivo da Previdência Social e a necessidade de preservação do equilíbrio entre suas receitas e despesas -, ferindo o equilíbrio financeiro e atuarial do RGPS. No limite, tal cenário significaria que, na prática, as próprias transferências previdenciárias (sob a forma de aposentadorias pagas mensalmente) poderiam financiar as cotizaçóes adicionais feitas pelo aposentado, posteriormente utilizadas para a majoração do valor dos benefícios. Nesse sentido, o instituto da desaposentação, via reversão da aposentadoria já obtida com o objetivo exclusivo de possibilitar o recebimento de benefício mais vantajoso (no mesmo ou em outro regime previdenciário), ameaçaria significativamente a sustentabilidade do RGPS.

Os mecanismos de incentivo à postergação do requerimento de aposentadoria tenderiam a se tornar inócuos. Para além dos casos excepcionais, nos quais a atividade laboral já seria dificultosa - por invalidez, enfermidade crônica e/ou desemprego de longa duração, por exemplo, todos fenômenos tratados de modo específico pelo RGPS ou por outras políticas públicas -, os segurados tentariam

\footnotetext{
6. A Lei o 13.183/2015, que instituiu a referida fórmula, afeta as regras para a concessão da aposentadoria por tempo de contribuição, levando em consideração o número de pontos alcançados ao somar a idade e o tempo de contribuição do segurado. Alcançados os pontos necessários - atualmente, 85 (mulheres) ou 95 (homens) -, é possível receber 0 benefício integral, sem aplicação do fator previdenciário. A progressividade ajusta, com o passar do tempo, os pontos necessários para esse fim, segundo a evolução da expectativa de sobrevida dos brasileiros.

7. Claro que no curto prazo nem todos teriam vantagens e que o efeito imediato da desaposentação poderia ser determinado por diversos fatores, por exemplo, a idade no momento da aposentadoria e da desaposentação (bem como a sobrevida nestas idades exatas), o tempo transcorrido entre a aposentadoria e o hipotético pedido de desaposentação, o sexo do segurado, o histórico dos salários de contribuição e o valor do salário de benefício (igual ou superior ao piso previdenciário, nos períodos pré e pós-aposentadoria) e seu padrão de inserção no mercado de trabalho (em termos de formalidade e estabilidade no vínculo previdenciário, também pré e pós-aposentadoria), mas as potenciais mudanças comportamentais sobre os segurados tenderiam a produzir prejuízos financeiros e atuariais maiores no longo prazo. Para uma análise focalizada na Taxa Interna de Retorno (TIR), ver, por exemplo: Zanella, Carvalho e Afonso (2014).
} 
otimizar sua taxa de retorno, se aposentando na idade mínima e com o menor tempo de contribuição permitido, de modo a acumular os meios para a elevação da prestação mensal já durante o período de gozo de um benefício previdenciário. Isso contraria não apenas a lógica do RGPS, mas de qualquer regime de repartição simples, apoiado na solidariedade intra e intergeracional. Em termos concretos, tratava-se de uma alteração na lógica fundamental do sistema previdenciário, que se moldaria ao interesse do indivíduo - que ora o utilizaria como é (pay-as-you-go), ora o utilizaria como fosse mais conveniente para si - como se os aportes adicionais feitos se destinassem unicamente a financiar o seu benefício, como em regimes típicos de capitalização.

Ressalte-se ainda o caráter altamente regressivo da proposição, visto que os segurados que logram acumular as duas fontes de rendimento nessas condiçóes (aposentadoria precoce e rendimento do trabalho) pertencem normalmente aos décimos mais elevados da distribuição de renda nacional. Não raro, nessas posiçôes estâo justamente aqueles que recebem benefícios mais elevados e reúnem melhores condiçóes para estender sua permanência no mercado de trabalho. Em um cenário em que a sustentabilidade financeira e atuarial do RGPS já é bastante preocupante, seria difícil justificar a concessão de tamanhos subsídios para grupos já relativamente mais protegidos que a média da população brasileira. Embora todos estes argumentos (e outros, de cunho eminentemente jurídico) tenham sido exaustivamente debatidos, os princípios da solidariedade e da legalidade parecem ter sido os mais determinantes para a decisão final sobre o tema. O STF, em sua decisão, publicada no Diário da Justiça Eletrônico (DJE) no 231, de 27 de outubro de 2016, reconheceu que as contribuições compulsórias recolhidas dos trabalhadores após a aposentadoria dos segurados do RGPS (INSS) devem ser destinadas apenas ao custeio geral do sistema. A decisão sepultou a possibilidade de revisão de benefícios pela desaposentação, ou seja, a pretensão de renúncia de uma primeira aposentadoria e a posterior realização de novo cálculo de benefício com base em período adicional de contribuição. O Supremo Tribunal Federal fixou tese nos seguintes termos: "No âmbito do Regime Geral de Previdência Social (RGPS), somente lei pode criar benefícios e vantagens previdenciárias, não havendo, por ora, previsão legal do direito à desaposentação, sendo constitucional a regra do art. $18, \$ 2^{\circ}$, da Lei no $8.213 / 1991 ”\left(\right.$ STF, 2016). ${ }^{8}$

8. Nos termos de seu art. 18, § 2ㅜㅡ a Lei no 8.213/1991 estabelece que 0 aposentado pelo RGPS que permanecer em atividade sujeita a este regime, ou a ele retornar, não fará jus a prestação alguma da Previdência Social em decorrência do exercício dessa atividade, exceto ao salário-família e à reabilitação profissional, quando empregado. Vale ressaltar que no final de 2015 chegou a ser aprovado um dispositivo legal que regulamentava a desaposentação, posteriormente vetado pela então presidente Dilma Rousseff. Tal dispositivo foi na Medida Provisória no 676/201, transformada na Lei № 13.183/2015, quando de sua tramitação na Câmara dos Deputados. 


\section{ACOMPANHAMENTO DA POLÍTICA PREVIDENCIÁRIA}

\subsection{Evolução da cobertura previdenciária}

\subsubsection{População ocupada}

Ao longo da última década (em particular, entre 2002 e 2013), o país experimentou uma expansão importante dos principais indicadores de formalidade trabalhista e previdenciária. As bases de dados do então Ministério da Previdência Social (MPS), hoje incorporado ao Ministério da Fazenda (MF), e do Ministério do Trabalho e Emprego (MTE), corroboram essa afirmação: o primeiro registrou aumento importante no volume de contribuintes do RGPS; o segundo, ao menos até 2013, acumulou recordes nos saldos entre admitidos e desligados e, consequentemente, no estoque de ocupados formais. Os levantamentos feitos pelo Instituto Brasileiro de Geografia e Estatística (IBGE) refletem esses resultados, tanto nos censos demográficos quanto na Pnad.

Como os menores de 16 anos de idade (salvo os contratados na condição de aprendizes) não podem legalmente contribuir para a Previdência Social, e os maiores de 59 anos dificilmente começarão a fazê-lo (pois, nessa idade, dificilmente atingirão as carências mínimas para os benefícios planejados), a análise proposta fica restrita ao grupo de ocupados com idade entre 16 e 59 anos. Outro ponto que sustenta esta opção, notadamente com respeito ao limite superior do recorte etário, é a idade média de aposentadoria no RGPS, regime que reúne a maior parte dos beneficiários da Previdência Social no Brasil: em 2015, consideradas a aposentadoria por idade, a aposentadoria por invalidez (previdenciária e acidentária) e a aposentadoria por tempo de contribuição, os segurados se aposentaram com idade média de 57,5 anos de idade (54,73 anos, se tomada apenas a ATC). Vale mencionar ainda o Estatuto do Idoso, em vigor desde 2003 (Lei no 10.741 , de $1^{\circ}$ de outubro de 2003), que se destina a regular os direitos assegurados às pessoas com idade igual ou superior a 60 anos.

Seriam dois os indicadores básicos de interesse: a taxa de cobertura e a taxa de proteção previdenciária. Enquanto a taxa de cobertura previdenciária consiste no volume de ocupados que contribuem para a Previdência Social como proporção da população ocupada, a população protegida é composta por quatro segmentos: ${ }^{9}$ i) os contribuintes (segurados ativos) do RGPS; ii) os segurados ativos de regimes específicos para militares e servidores públicos; iii) os chamados segurados especiais (trabalhadores rurais que exercem suas atividades individualmente ou em regime de economia familiar, cobertos mesmo não declarando contribuição para a previdência,

9. Esse conceito foi aprovado pelo Conselho Nacional de Previdência Social (CNPS) em 2004, quando então deu origem ao indicador oficial de cobertura previdenciária da população ocupada. Há outros indicadores possíveis e relevantes, mas este possui a clara vantagem de melhor incorporar as peculiaridades da Previdência Social brasileira. 
já que sua contribuição se dá sobre a eventual comercialização da produção rural); e iv) os náo contribuintes que recebem algum benefício continuado (previdenciário ou assistencial).

Isso posto, tem-se que, de acordo com a Pnad 2015 (IBGE, 2015), última disponível, naquele ano existiam no país 86,7 milhões de pessoas ocupadas com idade entre 16 e 59 anos. Este contingente, quando contraposto ao subgrupo de pessoas consideradas protegidas ou cobertas nessa mesma faixa etária, resultou em uma taxa de proteção de $72,5 \%$ e em uma cobertura de $64,9 \%$. Em termos agregados, isso significa que, de cada dez trabalhadores brasileiros, cerca de sete estão protegidos pela Previdência Social, ou seja, contribuem para algum regime previdenciário público ou são segurados especiais ou, embora não contribuam e não pertençam ao regime especial rural, já são beneficiários da Previdência Social ou da assistência social. ${ }^{10} \mathrm{~A}$ proteção previdenciária é atualmente estatisticamente equivalente entre homens $(72,4 \%)$ e mulheres $(72,7 \%)$, enquanto a cobertura previdenciária resulta ligeiramente superior entre as mulheres (homens: 64,0\%; mulheres: $66,1 \%)$. O indicador de proteção se mantém relativamente estável nos últimos três anos, mas o contingente de protegidos assume, em 2015, o menor volume do triênio 2013-2015. Em outras palavras, a proporção de protegidos tem se mantido mais em função de reduções no denominador (redução na população ocupada, já um possível resultado da crise econômica enfrentada pelo país) do que em virtude de uma expansão na quantidade de ocupados protegidos.

TABELA 1

Proteção previdenciária, cobertura previdenciária e formalidade trabalhista dos ocupados entre 15 e 59 anos de idade, segundo sexo e categorias de trabalhadores - Brasil (2015)

\begin{tabular}{lrrrrrr}
\hline Categorias & \multicolumn{1}{c}{ Homens } & \multicolumn{1}{c}{$(\%)$} & \multicolumn{1}{c}{ Mulheres } & \multicolumn{1}{c}{$(\%)$} & \multicolumn{1}{c}{ Total } & $(\%)$ \\
\hline Contribuintes RGPS (A) & 28.585 .832 & \multicolumn{1}{c}{58,2} & 20.832 .528 & 55,4 & 49.418 .360 & 57,0 \\
\hline Contribuintes RPPS (B) & 2.836 .691 & 5,8 & 4.000 .192 & 10,6 & $\mathbf{6 . 8 3 6 . 8 8 3}$ & 7,9 \\
$\quad$ Militares & 316.506 & 0,6 & 30.616 & 0,1 & $\mathbf{3 4 7 . 1 2 2}$ & 0,4 \\
Estatutários & 2.520 .185 & 5,1 & 3.969 .576 & 10,6 & $\mathbf{6 . 4 8 9 . 7 6 1}$ & 7,5 \\
Segurados especiais' (RGPS) (C) & 3.793 .974 & 7,7 & 1.999 .860 & 5,3 & $\mathbf{5 . 7 9 3 . 8 3 4}$ & 6,7 \\
Não contribuintes (D) & 13.880 .524 & 28,3 & 10.747 .469 & 28,6 & $\mathbf{2 4 . 6 2 7 . 9 9 3}$ & 28,4 \\
Total (E = A + B + C + D) & 49.097 .021 & 100,0 & 37.580 .049 & 100,0 & $\mathbf{8 6 . 6 7 7 . 0 7 0}$ & 100,0 \\
Beneficiários não contribuintes2 (F) & 316.129 & 0,6 & 487.773 & 1,3 & $\mathbf{8 0 3 . 9 0 2}$ & 0,9 \\
\hline & & & & & & (Continua)
\end{tabular}

$\overline{\text { 10. Como a classificação }}$ das áreas urbanas e rurais é feita de acordo com a legislação vigente quando da realização dos censos demográficos, mesmo que a legislação tenha alterado a classificação de determinadas áreas no período intercensitário, a definição estabelecida por ocasião de um censo demográfico é mantida para as Pnads realizadas até o próximo levantamento censitário. Consequentemente, os dados por situação urbana e rural não captam integralmente a sua evolução, sendo que as diferenças se intensificam na medida em que os resultados obtidos se afastam do ano de realização do último censo demográfico. Como essa classificação é utilizada para a identificação dos segurados especiais, no tempo pode haver alguma perda de acurácia na comparabilidade. De qualquer modo, o peso maior do indicador é atribuído à natureza da atividade econômica desenvolvida pelo trabalhador, minimizando o problema mencionado. 


\begin{tabular}{|c|c|c|c|c|c|c|}
\hline Categorias & Homens & $(\%)$ & Mulheres & $(\%)$ & Total & $(\%)$ \\
\hline Contribuintes RGPS (A) & 28.585 .832 & 58,2 & 20.832 .528 & 55,4 & 49.418 .360 & 57,0 \\
\hline Trabalhadores socialmente protegidos $(A+B+C+F)$ & 35.532 .626 & 72,4 & 27.320 .353 & 72,7 & 62.852 .979 & 72,5 \\
\hline Trabalhadores socialmente desprotegidos (D - F) & 13.564 .395 & 27,6 & 10.259 .696 & 27,3 & 23.824.091 & 27,5 \\
\hline $\begin{array}{l}\text { Desprotegidos com rendimento igual ou superior a } \\
1 \text { salário minimo }\end{array}$ & 8.989 .040 & 18,3 & 4.246 .511 & 11,3 & 13.235.551 & 15,3 \\
\hline $\begin{array}{l}\text { Desprotegidos com rendimento inferior a } 1 \\
\text { salário mínimo }\end{array}$ & 4.379 .829 & 8,9 & 5.884 .980 & 15,7 & 10.264 .809 & 11,8 \\
\hline Desprotegidos com rendimento ignorado & 195.526 & 0,4 & 128.205 & 0,3 & 323.731 & 0,4 \\
\hline \multicolumn{7}{|c|}{ Indicadores básicos sobre a população ocupada total (16 a 59 anos) } \\
\hline Indicadores & \multicolumn{2}{|c|}{$\begin{array}{c}\text { Homens } \\
(\%)\end{array}$} & \multicolumn{2}{|c|}{$\begin{array}{l}\text { Mulheres } \\
(\%)\end{array}$} & \multicolumn{2}{|c|}{$\begin{array}{c}\text { Total } \\
(\%)\end{array}$} \\
\hline Proteção previdenciária & \multicolumn{2}{|c|}{72,4} & \multicolumn{2}{|c|}{72,7} & \multicolumn{2}{|c|}{72,5} \\
\hline Formalidade previdenciária & \multicolumn{2}{|c|}{64,0} & \multicolumn{2}{|c|}{66,1} & \multicolumn{2}{|c|}{64,9} \\
\hline Formalidade trabalhista & \multicolumn{2}{|c|}{55,4} & \multicolumn{2}{|c|}{55,6} & \multicolumn{2}{|c|}{55,6} \\
\hline
\end{tabular}

Fonte: IBGE (2015).

Elaboração dos autores.

Notas: ${ }^{1}$ Moradores da zona rural dedicados a atividades agrícolas, nas seguintes posições na ocupação: sem carteira, conta própria, produção para próprio consumo, construção para próprio uso e não remunerados, respeitada a idade entre 15 e 59 anos.

${ }^{2}$ Ocupados (excluídos os segurados especiais) que, apesar de não contribuírem, recebem benefício previdenciário ou assistencial de caráter continuado.

Na série histórica harmonizada, ${ }^{11}$ o indicador de proteção agregado de 2015 parece consolidar uma relativa estabilidade, após uma mudança de tendência observada desde 2003, ainda que os efeitos da crise econômica recente - acentuada justamente após o último ano de referência da Pnad - possam afetar negativamente este resultado. No período 1992-2002, o contingente de protegidos cresceu proporcionalmente menos que em relaçáo à população ocupada total com o mesmo recorte etário, fazendo com que a taxa de proteção diminuísse, passando de $66,2 \%$ (1992) para 61,8\% (2002). Ambos os sexos registraram piora, mas entre as mulheres esse fenômeno foi menos significativo.

Entre 2002 e 2013 (ano seguido de um arrefecimento no ritmo de evolução), houve melhora visível nesse indicador, sendo que a recuperação se deu para homens e, em especial, para as mulheres, movimento que contribuiu para a redução das diferenças entre sexo na proteção previdenciária (protegidos/ocupados). Outra conclusáo óbvia, dada pela comparaçáo das linhas totais do gráfico 1, é a reduçáo da diferença entre os dois indicadores previdenciários aqui apresentados, diferença essa que alcançou 17,1 p.p., em 1992, e, no último ano da série, situava-se em 6,7 p.p. A diferença ainda é significativa, mas se reduz paulatinamente no tempo.

11. Como até 2003 a pesquisa não incluía as áreas rurais da região Norte, salvo de Tocantins, optou-se pela construção de uma série histórica harmonizada, que considera apenas as variáveis e coberturas geográficas presentes em todas as edições da Pnad utilizadas nesta nota. 


\section{GRÁFICO 1}

Proteção previdenciária' e cobertura previdenciária da população ocupada, de 15 a 59 anos de idade, segundo sexo - Brasil (1992-2015)²

(Em \%)

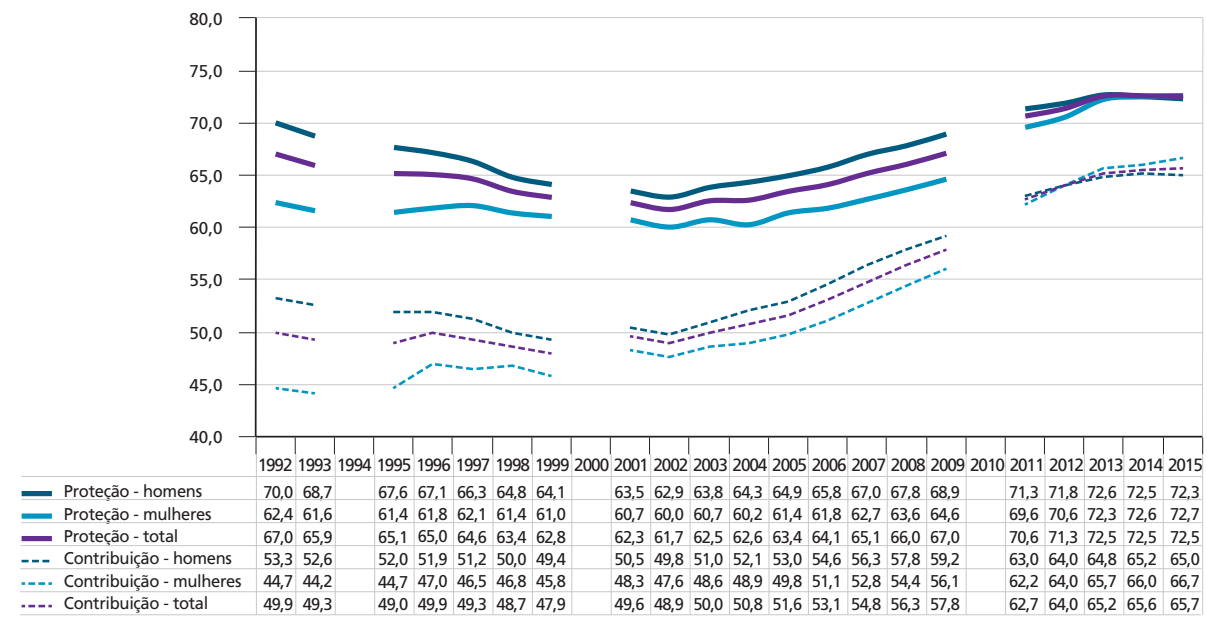

Fontes: Pnads/IBGE (vários anos).

Elaboração dos autores.

Notas: ${ }^{1}$ Muitos beneficiários de BPC, concedidos com base na Loas (Lei no 8.472, de 7 de dezembro de 1993), não diferenciam seus benefícios daqueles de natureza previdenciária, razão pela qual muitos podem ter respondido afirmativamente à questão da Pnad que busca identificar beneficiários de aposentadorias e pensões do Instituto de Previdência Oficial. Dado que o indicador de proteção previdenciária inclui beneficiários não contribuintes, é possível que aí se encontrem beneficiários da assistência social. Como a escala desse programa assistencial é limitada, ao menos diante da grandeza dos números previdenciários, esse risco tende a ser tolerável.

${ }^{2}$ Exclusive áreas rurais da região Norte (salvo Tocantins).

O indicador agregado de cobertura (contribuintes/ocupados) oculta diferenças marcantes nas tendências para homens e mulheres durante parte significativa do período considerado. A proporção de contribuintes (principal componente do indicador de proteçáo) pode ter caído para os homens entre 1992 e 2002, comprometendo assim o resultado global, mas entre as mulheres a tendência prevalente foi de expansão desta relação entre contribuintes e ocupados. A proporção de ocupados contribuintes entre as mulheres parece, inclusive, indicar tendência a superar, com significância estatística, a medida masculina, hipótese que deverá ser testada nos anos seguintes, quando os efeitos da crise econômica atual puderem ser melhor avaliados.

No tocante ao indicador geral de proteção previdenciária (protegidos/ocupados), a desagregação por categorias de segurados revela que o peso do subgrupo formado por beneficiários não contribuintes caiu ligeiramente no período 1992-2015, com um pequeno aumento na primeira metade da série e uma subsequente retração mais que proporcional (gráfico $2 \mathrm{C}$ ). Para militares e estatutários, a parte inicial da série revela estabilidade relativa, seguida de ligeira expansão, movimento que 
predomina no saldo final. Entre os segurados especiais, houve queda contínua de sua participação no total de ocupados - de 15,7\% (1992) para 5,8\% (2015), uma diminuição de quase 10 p.p. no tempo. O principal fator explicativo dos resultados acumulados, portanto, é a expansão no contingente de contribuintes do RGPS, grupo que ampliou substantivamente sua presença na população ocupada brasileira.

\section{GRÁFICO 2}

Decomposição do indicador de proteção previdenciária da população ocupada, de 15 a 59 anos de idade, segundo sexo - Brasil (1992-2015) ${ }^{1}$

(Em \%)

$2 \mathrm{~A}$ - Homens

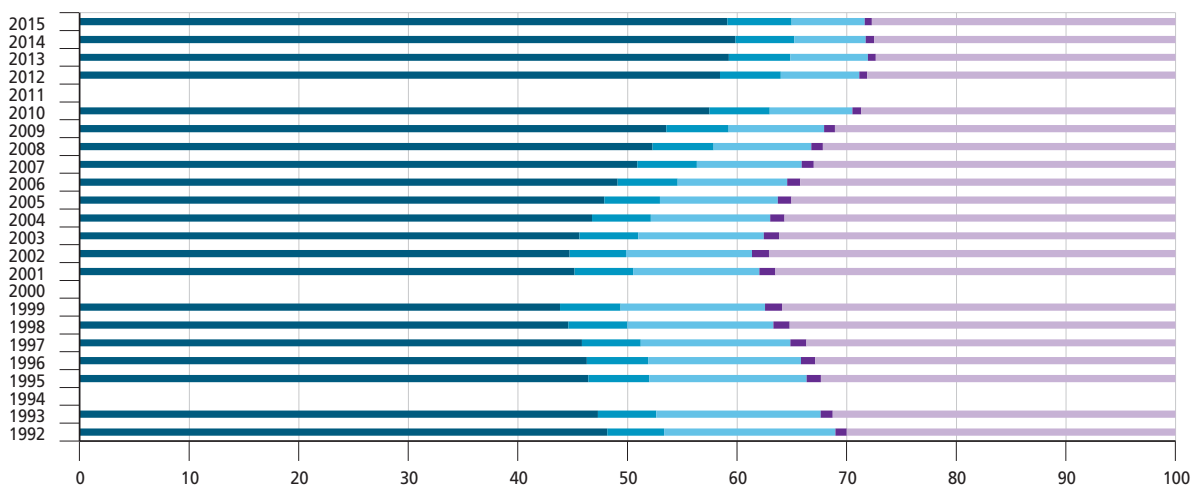

199219931994199519961997199819992000200120022003200420052006200720082009201020112012201320142015

\section{- RGPS}

- RPPS e militares

- Segurados especiais

- Beneficiários não contribuintes

ఐDesprotegidos
$48,147,3$

$\begin{array}{lll}5,2 & 5,3\end{array}$

$15,6 \quad 15,0$

\begin{tabular}{|l|l|}
1,0 & 1,1 \\
\hline
\end{tabular}

$\begin{array}{lll}30,0 & 31,3\end{array}$ $\begin{array}{llllll}46,4 & 46,3 & 45,8 & 44,6 & 43,8\end{array}$

\begin{tabular}{|l|l|l|l|l|}
5,6 & 5,6 & 5,4 & 5,4 & 5,5
\end{tabular}

$\begin{array}{llllll}14,4 & 13,9 & 13,7 & 13,3 & 13,2\end{array}$

\begin{tabular}{|l|l|l|l|l|}
\hline 1,3 & 1,3 & 1,4 & 1,5 & 1,6 \\
\hline
\end{tabular}

\begin{tabular}{l|l|l|l|l|}
32,4 & 32,9 & 33,7 & 35,2 & 35,9
\end{tabular}

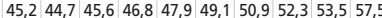

\begin{tabular}{|l|l|l|l|l|l|l|l|l|l|}
5,3 & 5,1 & 5,3 & 5,4 & 5,1 & 5,5 & 5,4 & 5,6 & 5,7 & 5,5 \\
\hline
\end{tabular}

\begin{tabular}{lllllllllll|l}
11,5 & 11,5 & 11,5 & 10,9 & 10,7 & 10,0 & 9,6 & 8,9 & 8,7 & 7,5 \\
\hline
\end{tabular}

\begin{tabular}{|l|l|l|l|l|l|l|l|l|l|}
1,5 & 1,5 & 1,4 & 1,3 & 1,2 & 1,2 & 1,1 & 1,0 & 1,0 & 0,8 \\
\hline
\end{tabular}

$\begin{array}{lllllllllll}36,5 & 37,1 & 36,2 & 35,7 & 35,1 & 34,2 & 33,0 & 32,2 & 31,1 & 28,7\end{array}$
$58,4 \quad 59,259,959,1$

$\begin{array}{lllll}5,5 & 5,6 & 5,4 & 5,9\end{array}$

\begin{tabular}{ll|l|l|}
7,2 & 7,1 & 6,5 & 6,7
\end{tabular}

$\begin{array}{llll}0,7 & 0,7 & 0,8 & 0,7\end{array}$

$\begin{array}{lllll}28,2 & 27,4 & 27,5 & 27,7\end{array}$

\section{B - Mulheres}

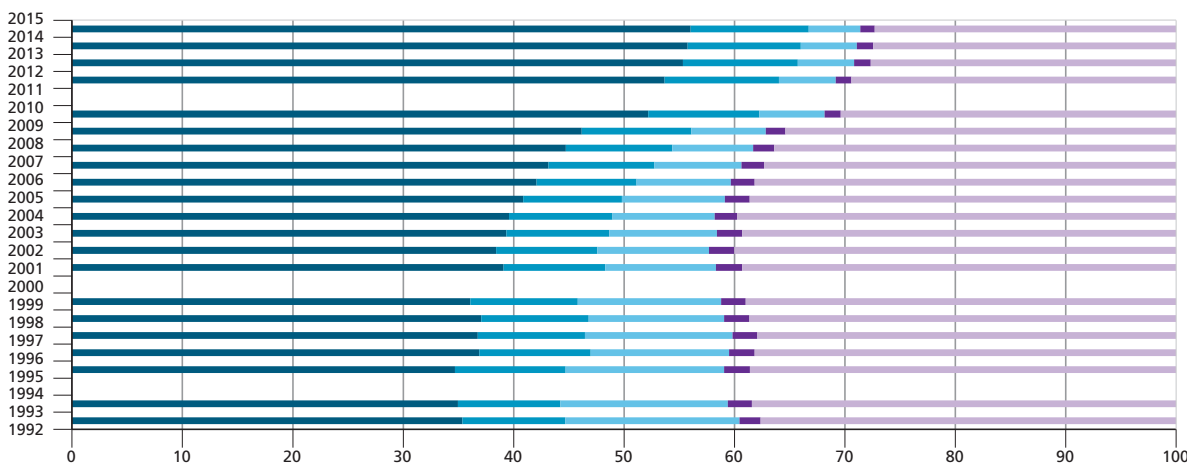

199219931994199519961997199819992000200120022003200420052006200720082009201020112012201320142015

- RGPS

- RPPS e militares

Segurados especiais

tes1,9 2,2

Desprotegidos $\begin{array}{lllll}34,7 & 36,9 & 36,7 & 37,1 & 36,1\end{array}$

\begin{tabular}{|l|l|l|l|l|}
\hline 10,0 & 10,1 & 9,7 & 9,7 & 9,7
\end{tabular}

$\begin{array}{lllllll}14,3 & 12,5 & 13,4 & 12,3 & 13,0\end{array}$

\begin{tabular}{l|l|l|l|l|}
2,3 & 2,3 & 2,3 & 2,3 & 2,2
\end{tabular}

$38,6 \quad 38,2 \quad 37,938,6 \quad 39,0$
$39,1 \quad 38,439,3 \quad 39,640,8 \quad 42,143,244,746,252,2$

\begin{tabular}{|l|l|l|l|l|l|l|l|l|l|}
9,2 & 9,2 & 9,3 & 9,4 & 9,0 & 9,1 & 9,6 & 9,6 & 9,9 & 10,0 \\
\hline
\end{tabular}

\begin{tabular}{|l|l|l|l|l|l|l|l|l|l|}
10,0 & 10,1 & 9,8 & 9,3 & 9,3 & 8,5 & 7,9 & 7,3 & 6,8 & 5,9 \\
\hline
\end{tabular}

\begin{tabular}{|l|l|l|l|l|l|l|l|l|l|}
\hline 2,4 & 2,3 & 2,3 & 2,0 & 2,2 & 2,1 & 2,0 & 1,9 & 1,8 & 1,4 \\
\hline
\end{tabular}

$\begin{array}{lllllllllll}39,3 & 40,0 & 39,3 & 39,8 & 38,6 & 38,2 & 37,3 & 36,4 & 35,4 & 30,4\end{array}$
$53,7 \quad 55,3 \quad 55,8 \quad 56,0$ \begin{tabular}{l|l|l|l|}
10,4 & 10,4 & 10,2 & 10,7
\end{tabular} \begin{tabular}{l|l|l|l|}
5,1 & 5,1 & 5,1 & 4,7
\end{tabular} \begin{tabular}{|l|l|l|l|}
1,4 & 1,5 & 1,5 & 1,3 \\
\hline
\end{tabular} \begin{tabular}{ll|l|l|l|}
29,4 & 27,7 & 27,4 & 27,3
\end{tabular} 
2C - Total (homens e mulheres)

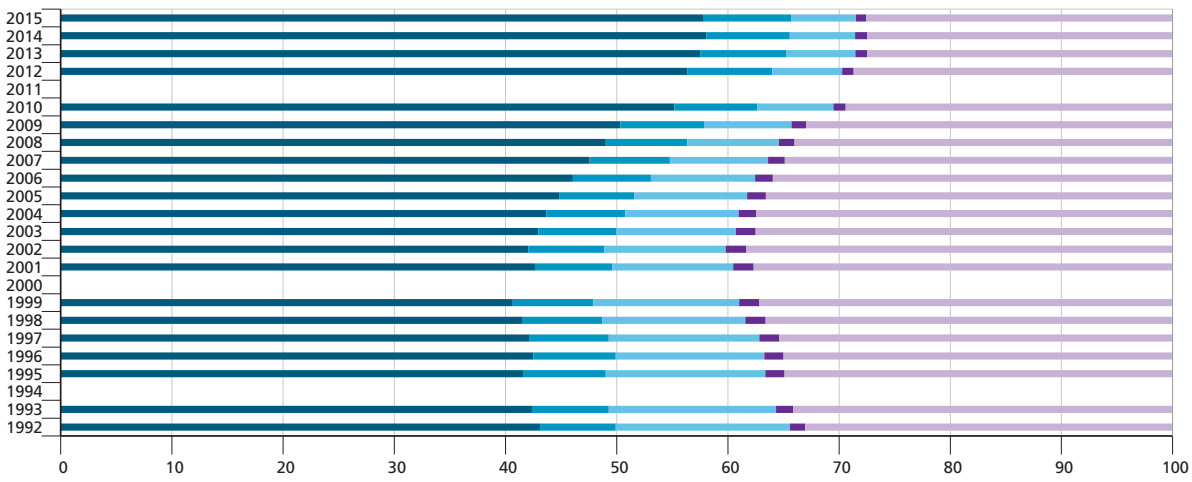

\begin{tabular}{|c|c|c|c|c|c|c|c|c|c|c|c|c|c|c|c|c|c|c|c|c|c|}
\hline & 199 & & & & & & & 001 & & & 004 & & & 007 & 2008 & 82009 & 92010 & 1201 & 201 & & 42015 \\
\hline RGPS & 43,1 & 42,4 & 41,6 & 42,5 & 42,2 & 41,6 & 40,6 & 42,6 & 42,1 & 43,0 & 43,7 & 44,9 & 46,0 & 47,6 & 49,0 & 50,3 & 355,2 & 56,4 & 57,5 & 58,0 & 57,8 \\
\hline Segurados especiais & 15,7 & 15,1 & 14,4 & 13,4 & 13,5 & 12,9 & 13,1 & 10,9 & 10,9 & 10,7 & 10,2 & 210,1 & 9,4 & 8,8 & 8,2 & 7,9 & 6,8 & 6,3 & 6,2 & 5,9 & 5,8 \\
\hline Desprotegidos & 33,0 & 34,1 & 34,9 & 35,0 & 35,4 & 36,6 & 37,2 & 37,7 & 38,3 & 37,5 & 37,4 & 436,6 & 535,9 & 34,9 & 34,0 & 33,0 & 029,4 & 28,7 & 27,5 & 27,5 & 27,5 \\
\hline
\end{tabular}

Fontes: Pnads/IBGE (vários anos).

Elaboração dos autores.

Nota: ${ }^{1}$ Exclusive áreas rurais da região Norte (salvo Tocantins).

$\mathrm{Na}$ abertura por sexo, os beneficiários não contribuintes pouco alteraram sua importância relativa no volume de ocupados protegidos. Muito embora sua relevância geral (e, principalmente, no meio rural) siga inegável, os segurados especiais perderam espaço para homens e mulheres, sendo que entre as últimas esse movimento se mostrou um pouco mais intenso. Os estatutários (principalmente) e os militares aumentaram sua participação na população ocupada, mas as mulheres parecem ter mais fortemente se beneficiado disso - entre outros motivos, pela natureza das vagas oferecidas (não raro, concentradas em ocupaçôes ainda mais comumente exercidas por mulheres), pela maior igualdade de oportunidades nos métodos tradicionais de seleção de trabalhadores no serviço público e pela melhoria no perfil educacional feminino - que sistematicamente supera o masculino em qualificação, quando a referência é o número de anos de estudo no sistema educacional formal.

Ao longo de todo o período (1992-2015), apesar dos resultados preocupantes no último ano (estabilidade no indicador previdenciário, mas com redução não desprezível no nível de ocupaçáo), o grande avanço se deu justamente na proporção de contribuintes do RGPS. Na série histórica harmonizada masculina, houve variação positiva de $22,8 \%$ na participação desse grupo na população ocupada (de 48,1\% em 1992, para 59,1\% em 2015); entre as mulheres, a variação foi ainda mais expressiva $(+58,5 \%)$, com esse indicador subindo de 35,3\%, em 1992, para $56,0 \%$, em 2015.

A expansão dos níveis de cobertura e proteção foi expressiva, generalizada e também esteve bastante atrelada à população ocupada feminina, inclusive 
porque se observa um cenário mais positivo (embora ainda desigual) para a participação feminina no mundo do trabalho e, consequentemente, para sua inclusão previdenciária. O que chama atenção, no entanto, é que o ganho recente no indicador de proteção dos trabalhadores ocupados se deu mais em função da inclusão de contribuintes do RGPS do que pelo aumento na proporção de protegidos em qualquer outra das categorias consideradas. Essa variação, em pontos percentuais, foi bastante superior entre as mulheres comparativamente aos homens, o que virtualmente eliminou os diferenciais entre os sexos nesse quesito.

Os resultados agregados, positivamente generalizáveis para os principais grupos integrantes da população ocupada (rurais e urbanos; homens e mulheres), também se respaldam na evolução dos indicadores calculados para as diferentes categorias de trabalhadores (ou melhor, para as distintas posiçôes na ocupação, tal como dispóe a Pnad): de modo geral, houve elevação da desproteção e da informalidade previdenciária em 1992 e 2002 e recuperação destes indicadores a partir de 2002 (gráficos 3A e 3B). Em 2015, último ano da série, a maioria dos grupos mantém uma relativa estabilidade no indicador, sendo o grupo dos trabalhadores domésticos aquele com o pior resultado. Muito embora a quantidade de ocupados nesta categoria venha declinando nos últimos anos, a quantidade de contribuintes passou a mais do que acompanhar este comportamento, resultando em ligeira queda na cobertura e na proteção entre 2015 e 2014.

Ressalte-se que o indicador de proteção previdenciária (gráfico 3A) desloca as curvas do gráfico 3B para cima, uma vez que mantém o denominador constante - população ocupada com idade entre 15 (na prática, 16) e 59 anos - e incorpora ao numerador (como trabalhadores protegidos) os segurados especiais e os ocupados que já recebem algum benefício permanente (aposentadoria e/ou pensão). As maiores diferenças são observadas nas categorias dos trabalhadores por conta própria e dos trabalhadores sem rendimento, em que a concentração de segurados especiais é mais elevada. 


\section{GRÁFICO 3}

Taxa de proteção e de contribuição previdenciária da população ocupada total, de 15 a 59 anos de idade, segundo a posição na ocupação - Brasil (1992-2015) ${ }^{1}$ (Em \%)

3A - Proteção previdenciária

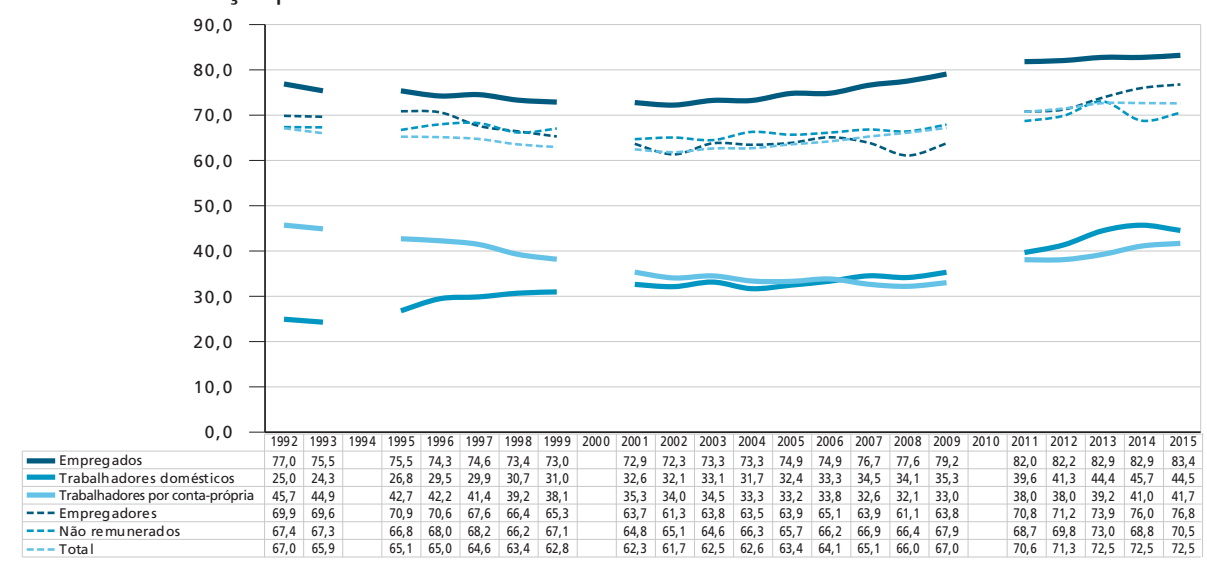

3B - Cobertura previdenciária

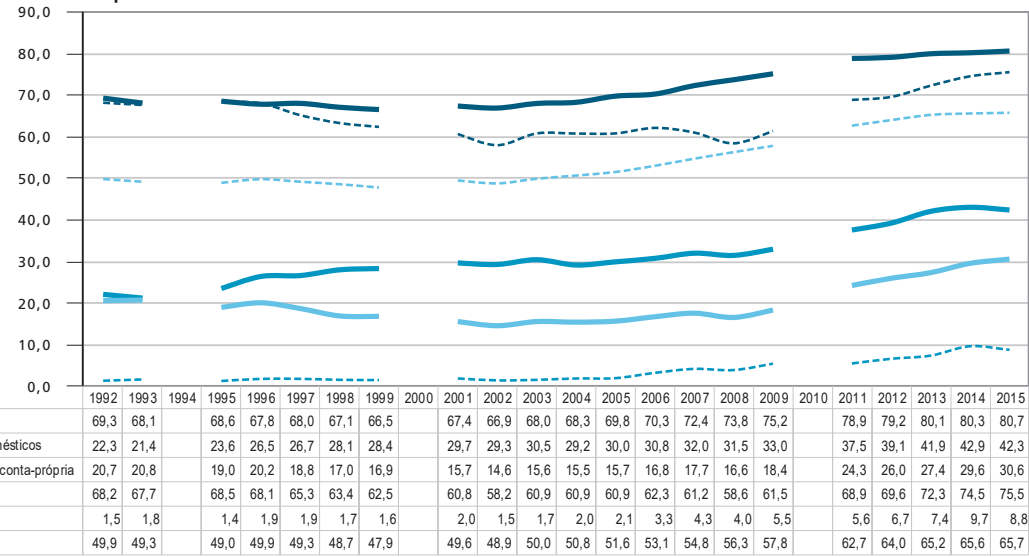

Fontes: Pnads/IBGE (vários anos)

Elaboração dos autores.

Nota: ${ }^{1}$ Exclusive áreas rurais da região Norte (salvo Tocantins).

Obs.: Considerando-se todos os ocupados, ou seja, incluídos no total os militares e os servidores públicos estatutários. 
Para além dos efeitos da instituição da figura do segurado especial, nos termos estabelecidos pela CF/1988, a expansão da cobertura entre os trabalhadores rurais também é explicada em parte por um aumento observado na proporção de trabalhadores agrícolas que - embora não possam ser incluídos no regime especial - contribuem para o RGPS. Os segurados do RGPS são agrupados em dois segmentos básicos: a clientela rural e a urbana. Estas clientelas são definidas em razão não do local de moradia (região censitária), mas sim de acordo com a natureza da atividade econômica que desenvolvem (agrícola/rural ou urbana).

O gráfico 4, resultado de uma tentativa de reproduzir esses grupos a partir dos dados da Pnad, evidencia (como esperado) que as diferenças entre os indicadores de proteção e contribuição são mínimas para a clientela urbana - dado que, por construção, se diferenciam apenas pelos beneficiários não contribuintes -, mas bastante expressivas para a clientela rural (na qual entram os segurados especiais). O valor do indicador global de cobertura variou 31,7\% no período 1992-2015, resultado naturalmente mais próximo ao alcançado pelo grupo de ocupados em atividades não agrícolas, o qual predomina com ampla vantagem na ocupação total - quase $90 \%$ do total de ocupados, inclusive militares e estatutários.

De todo modo, a taxa de cobertura agrícola (clientela rural), embora ainda bastante modesta (28,3\%), cresceu quase $147,8 \%$ entre 1992 e 2015, sendo que o período de maior expansão ocorreu a partir de 2002 - quando a cobertura foi mensurada em 12,7\%. Entre os trabalhadores não agrícolas (clientela urbana), após o ponto mínimo alcançado em 2002 (56,6\%), o indicador evoluiu positivamente até assumir o valor de $70,5 \%$ em 2015 - variação acumulada de $13,4 \%$ entre 1992 e 2015.

$\mathrm{O}$ indicador de proteção previdenciária, que chegou a regredir ao longo da primeira década analisada (1992-2002), apresentou incremento discreto entre a clientela rural. ${ }^{12}$ Entre os trabalhadores urbanos, tendências semelhantes foram registradas, mas estas se mostraram mais fortes e, também pelo peso das atividades urbanas na ocupação total, determinaram o padrão observado para o total de ocupados. A especificidade da previdência rural brasileira faz com que a proteção da clientela rural seja significativamente superior à urbana, situação improvável quando tomado o indicador de cobertura - como evidenciado no gráfico 4 .

\footnotetext{
12. Segundo a composição mais recente dos grupamentos de atividade definida pelo IBGE para a Pnad, o grupamento agrícola incorpora as seguintes atividades: i) agricultura, pecuária e serviços relacionados com estas atividades; ii) silvicultura, exploração florestal e serviços relacionados com estas atividades; e iii) pesca, aquicultura e atividades dos serviços relacionados com estas atividades.
} 
GRÁFICO 4

Taxa de proteção e de contribuição previdenciária dos ocupados, de 16 a 59 anos de idade, segundo clientelas (rural e urbana) do RGPS - Brasil (1992-2015) (Em \%)

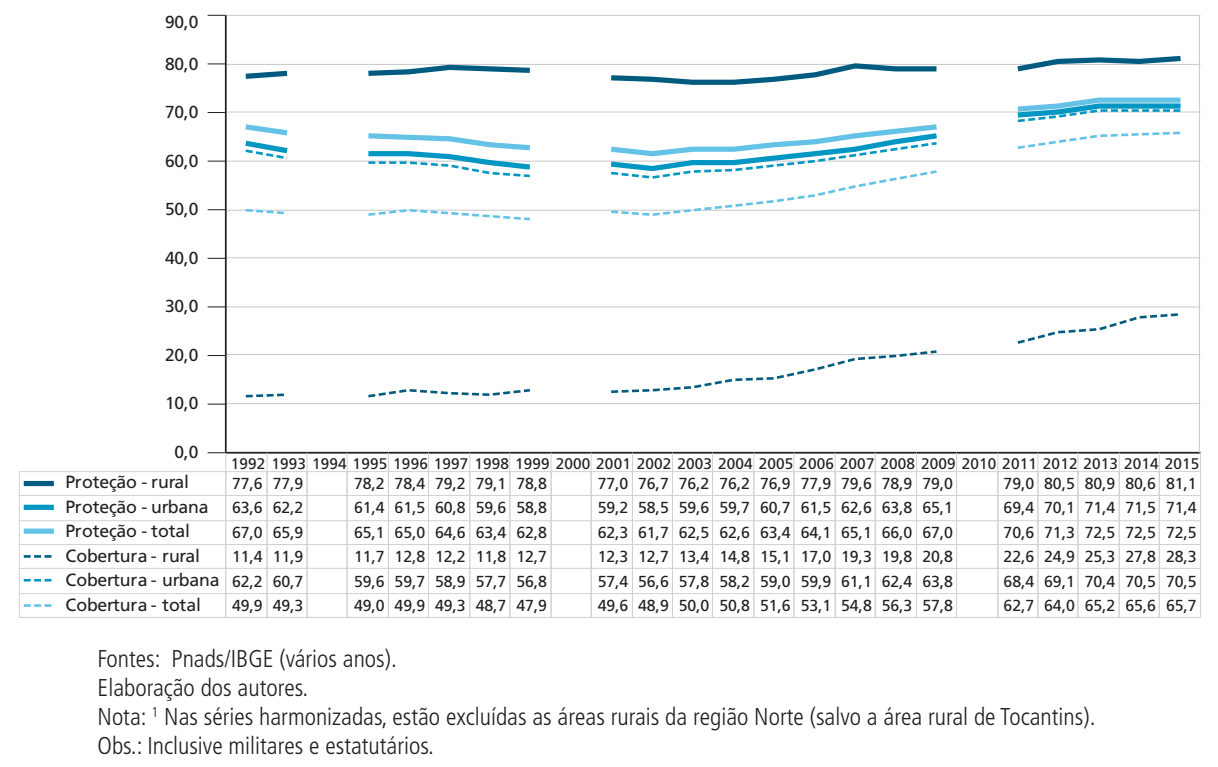

Apesar dos fenômenos relatados anteriormente com respeito ao declínio no volume de segurados especiais, a relevância da previdência rural brasileira para a proteção previdenciária dos trabalhadores brasileiros segue incontestável - aproximadamente $52 \%$ da clientela rural ocupada de 2015, com recorte etário de 16 a 59 anos de idade, se declara não contribuinte, mas encontra-se protegida na condiçáo de segurados especiais. Esses resultados ocultam fortes diferenças regionais e ainda sugerem impactos não desprezíveis da Previdência Social sobre o nível de pobreza individual (efeito direto) e familiar (efeito indireto), dado o potencial que as transferências previdenciárias podem assumir em áreas essencialmente rurais.

Por um lado, a queda no contingente de segurados especiais tem forçado o indicador de proteçáo para baixo; por outro, especialmente no período 2003-2015, o incremento na taxa de contribuição dos trabalhadores agrícolas tem servido para compensar esta tendência. Vale destacar que esse claro movimento de redução na quantidade absoluta de potenciais segurados especiais se deu possivelmente em razão da migração rural-urbana (bastante arrefecida nas últimas décadas) e, principalmente, 
da expansão da agroindústria e das atividades não agrícolas no meio rural, estas últimas associadas a um forte movimento de urbanização do meio rural. ${ }^{13}$

Quando analisados sob a ótica regional, dimensão importante em um país com a heterogeneidade socioeconômica e a amplitude geográfica do Brasil, os indicadores de cobertura e de contribuição previdenciária variam significativamente. Entre as 27 Unidades da Federação (UFs), aquelas das regióes Sul e Sudeste (exceto o Rio de Janeiro), além do Distrito Federal, apresentam níveis de proteção iguais ou superiores à média nacional; para o indicador de cobertura, superam ou igualam a média nacional todos os estados do Sul, Sudeste e Centro-Oeste.

\section{GRÁFICO 5}

Proteção previdenciária e taxa de cobertura previdenciária da população ocupada, entre 16 e 59 anos de idade, segundo UFs - Brasil (2015)

(Em \%)

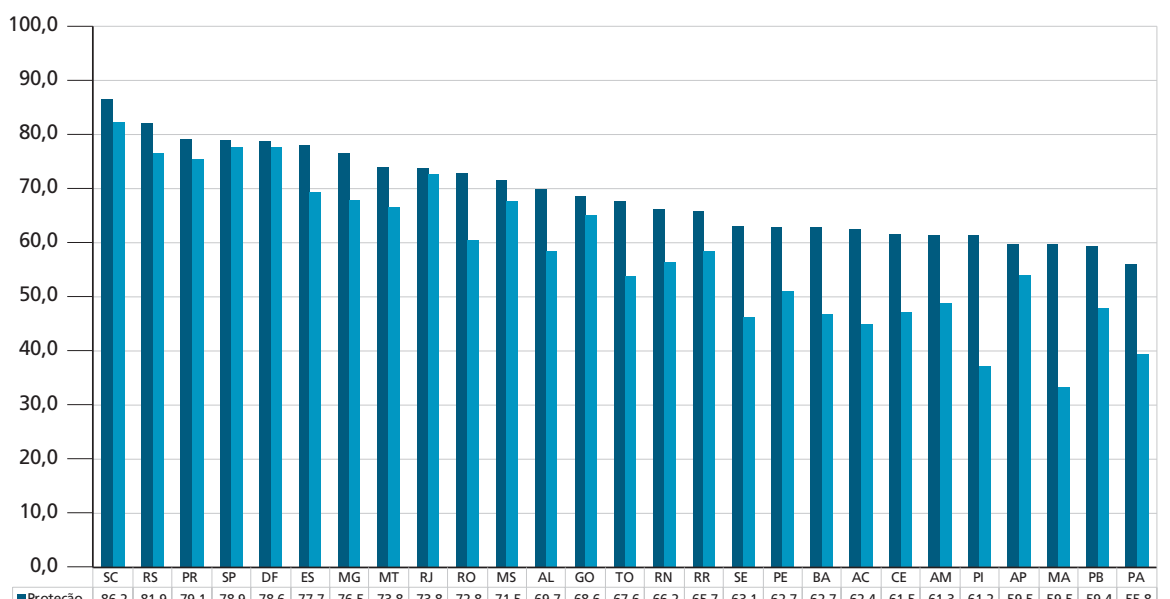

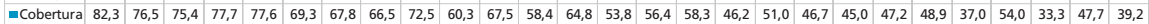

\section{Fonte: IBGE (2015).}

Elaboração dos autores.

Obs.: Inclusive militares e estatutários.

Entre as UFs com menor índice de proteção estão Pará, Amapá, Paraíba e Maranhão - todos com percentual de protegidos ligeiramente inferior a $60 \%$ (frente a uma média nacional de 72,5\%). Tendo em vista a unicidade do marco legal do RGPS em todo o Brasil, a explicação para estas disparidades tende a residir nas profundas desigualdades econômicas e sociais regionais existentes no país. Quando a referência é a taxa de cobertura previdenciária, as disparidades

13. Para evidências, na década de 1990, da associação entre interiorização da economia e incremento na ocupação rural não agrícola, ver Grossi, Silva e Campanhola (2001). Evidências mais recentes, associando os fenômenos da interiorização e da litoralização com a evolução da urbanização e da composição setorial da ocupação no país, podem ser obtidas em IBGE (2010). 
aumentam e a ordenação das UFs se altera. A maior diferença entre cobertura e proteçáo fica mesmo por conta da categoria dos segurados especiais. Estados como Maranhão, Piauí e Pará, com cobertura previdenciária (proporção de contribuintes sobre a populaçáo ocupada) inferior a $40 \%$, situam-se muito abaixo da média nacional quando se considera o indicador de contribuição (64,9\%). A diferença entre os dois indicadores (proteção e cobertura) chega a ser bastante expressiva (por exemplo, da ordem de 26 p.p., como no caso do Maranhão), fenômeno esse mais contundente nas regióes Norte e Nordeste.

Os segurados especiais respondem quase que isoladamente pelo ganho na taxa de proteção em relação à taxa de cobertura, situação que evidencia a importância da previdência rural para a proteção social da população brasileira, especialmente nas UFs com graus de desenvolvimento socioeconômico mais modestos. Justamente nos estados onde o mercado de trabalho é menos estruturado e dinâmico, com menor participaçáo de empregados com carteira de trabalho assinada no total de ocupados, a participação dos segurados especiais dentre os ocupados tende a ser superior à média do país.

Em suma, sob qualquer que seja a ótica considerada (proteção, cobertura ou formalidade trabalhista, para considerar as dimensôes tomadas como mais relevantes no contexto desta análise), houve aumentos expressivos na proporção da população ocupada que conta com a proteçấo de ao menos algum dos mecanismos tradicionais (e oficiais) de proteção social existentes no país. Houve avanços generalizados em todo o país, em todas as posiçóes na ocupação, em todos os ramos de atividade e para ambos os sexos. O destaque fica pelo protagonismo assumido pelo emprego assalariado formal, que cresceu e exerceu possível papel de catalisador dos demais movimentos. A dinâmica econômica positiva explica em grande parte este resultado, bem como as melhorias na contribuição autônoma.

Com respeito a esse último ponto, também vale mencionar três medidas implantadas para fomentar a inclusão previdenciária dos trabalhadores autônomos (trabalhadores por conta própria e empregadores): $i$ ) a equiparação de contribuintes individuais (CI pessoas físicas) a empregados, quando aqueles prestam serviços a empresas, medida consolidada em 2003, chamada informalmente de retenção obrigatória; ii) a instituição do Plano Simplificado de Inclusão Previdenciária (PSPS), em 2006, medida que reduziu (de 20\% para 11\%) a alíquota de CI recolhida sobre o valor do piso previdenciário; e iii) criação da figura do microempreendedor individual (MEI), em 2007. As duas primeiras açôes focam apenas a formalização previdenciária, enquanto o MEI se destina à legalização do pequeno empreendimento.

O MEI e o PSPS se destinam (ao menos em tese) ao contingente de autônomos desprotegidos e com baixos rendimentos, motivo pelo qual suas alíquotas de contribuição são bastante reduzidas. A retenção obrigatória, por sua vez, consiste no recolhimento compulsório, pelo contratante, da contribuição previdenciária de contribuintes individuais 
que prestam serviços a pessoas jurídicas, nos termos do art. 4º da Lei no ${ }^{\circ}$ 10.666/2003. Anteriormente à medida, ficava o contribuinte individual responsável pelo recolhimento de sua própria contribuição, cujo montante - respeitados os valores mínimo e máximo de cotização mensal - tendia a ser calculado sobre uma renda frequentemente autodeclarada pelo próprio segurado. Tais medidas, embora ainda careçam de avaliaçóes sistemáticas de seus impactos, podem ter influenciado - em alguma medida, ainda que marginalmente - as melhorias na cobertura desses trabalhadores.

Por seu turno, há que se investigar também possíveis migraçôes indesejadas entre as diferentes modalidades de filiação previdenciária, geradas por eventuais incentivos indesejados produzidos por estas medidas - por exemplo, a substituição de empregados com carteira ou de contribuintes individuais atuando como pessoas físicas por MEI, não sujeitos às obrigaçóes patronais válidas para a contratação de membros dos dois primeiros grupos e ainda beneficiados por alíquotas contributivas mais vantajosas. Esse risco também se apresenta para os trabalhadores domésticos, categoria que vem experimentando mudanças lentas, mas consistentes e contínuas, em sua composição, com a substituição gradativa de mensalistas (no âmbito do grupo, mais comumente protegidas por contrato formal de trabalho) por diaristas (mais frequentemente vinculadas ao RGPS na condição de contribuintes individuais).

\subsubsection{População idosa}

Entre os idosos, aqui definidos como aqueles com idade igual ou superior a 60 anos, a proteçấo previdenciária de 2015 foi estimada em 81,7\% (tabela 2). Os idosos socialmente protegidos - que recebiam aposentadoria e/ou pensão por morte (PPM) de qualquer regime previdenciário ou benefícios da assistência social (BPC) ou contribuíam para a Previdência Social - totalizavam 24 milhóes de pessoas em 2015, sendo 11,1 milhóes de homens e 12,8 milhôes de mulheres. A proteção social entre os homens chegava a $86,1 \%$, resultado superior ao observado entre as mulheres (78,3\%).

A maior parte dos idosos protegidos recebia aposentadoria, grupo em que preponderavam os homens. Estes também eram maioria entre os não beneficiários que contribuíam para a Previdência Social, fato explicado, principalmente, por se depararem com requisitos mais elevados de idade e/ou tempo de contribuição para o requerimento de aposentadorias. Entre os pensionistas e beneficiários que acumulavam pensão e aposentadoria, como era de se esperar, prevaleciam as mulheres, que em média possuem expectativa de vida mais elevada e tendem a mais frequentemente usufruir de pensôes deixadas por seus cônjuges. Esse resultado também é explicado pelo fato de que as mulheres idosas, atualmente com idade igual ou superior a 60 anos, entraram em idade ativa quando a realidade da inserção feminina no mercado de trabalho era bastante diversa daquela agora enfrentada pelas mulheres pertencentes à população em idade ativa (PIA). 


\section{TABELA 2}

Proteção previdenciária entre os idosos com 60 anos ou mais de idade, segundo sexo - Brasil (2015)

\begin{tabular}{lrrrrrrr}
\hline Categorias & Homens & $\begin{array}{c}\text { Participação } \\
\text { no total } \\
(\%)\end{array}$ & Mulheres & $\begin{array}{c}\text { Participação } \\
\text { no total } \\
(\%)\end{array}$ & Total & $\begin{array}{c}\text { Participação } \\
\text { no total } \\
(\%)\end{array}$ \\
\hline Aposentados & 9.361 .477 & 72,3 & 7.986 .329 & 48,6 & $\mathbf{1 7 . 3 4 7 . 8 0 6}$ & 59,1 \\
Pensionistas & 169.443 & 1,3 & 2.494 .049 & 15,2 & $\mathbf{2 . 6 6 3 . 4 9 2}$ & 9,1 \\
Aposentados e pensionistas & 345.185 & 2,7 & 1.831 .750 & 11,1 & $\mathbf{2 . 1 7 6 . 9 3 5}$ & 7,4 \\
Contribuintes (não beneficiários) & 1.266 .812 & 9,8 & 554.048 & 3,4 & $\mathbf{1 . 8 2 0 . 8 6 0}$ & 6,2 \\
Protegidos & 11.142 .917 & 86,1 & 12.866 .176 & 78,3 & $\mathbf{2 4 . 0 0 9 . 0 9 3}$ & 81,7 \\
Desprotegidos & 1.802 .544 & 13,9 & 3.562 .333 & 21,7 & $\mathbf{5 . 3 6 4 . 8 7 7}$ & 18,3 \\
Total de residentes & 12.945 .461 & 100,0 & 16.428 .509 & 100,0 & $\mathbf{2 9 . 3 7 3 . 9 7 0}$ & 100,0 \\
\hline
\end{tabular}

Fonte: Pnad//BGE (2015).

Elaboração dos autores.

Em relação aos idosos, apesar do desequilíbrio que ainda persiste na proteção de homens e mulheres e de algumas oscilaçôes em determinados anos da série, os dados da Pnad para a década de 1990 apontaram para uma tendência de expansão da proteção previdenciária, enquanto para os anos mais recentes se observa uma relativa estabilidade do indicador (gráfico 6). Na série harmonizada, a parcela da população idosa protegida passou de 74,1\% em 1992 para $81,7 \%$ em 2015 . Tal melhora, especialmente aquela ocorrida na primeira parte da série histórica, resulta em grande medida do aumento da proteção de idosos do sexo feminino, uma vez que a série referente aos homens idosos pouco cresceu desde 1993. A estabilidade do indicador de proteção ocorre mesmo em um cenário de crescimento da populaçáo com 60 anos ou mais de idade: a quantidade absoluta de desprotegidos também aumentou, mas o fez a taxas menores que as observadas para a população idosa em geral.

$\mathrm{O}$ aumento da cobertura entre as idosas pode ser resultado do incremento na participação das mulheres na população ocupada, fenômeno intensificado nas últimas décadas. No longo prazo, com tudo mais constante, a confirmação desta tendência pode reduzir as disparidades na proteção de homens e mulheres idosos. A evolução destes indicadores de proteção previdenciária entre os idosos tende a estar fortemente associada ainda à instituição da categoria de Segurado Especial, regulamentada em 1991, que possibilitou a expansão da cobertura previdenciária no meio rural. Além disso, vale mencionar que o comportamento positivo na 
primeira metade da série pode estar relacionado também ao aumento do número de beneficiários de BPC previstos na Loas, alterada pelo Estatuto do Idoso. ${ }^{14}$

\section{GRÁFICO 6}

Idosos de 60 anos ou mais que recebem aposentadoria e/ou pensão ou que contribuem para algum regime previdenciário - Brasil (1992-2015) ${ }^{1}$ (Em \%)

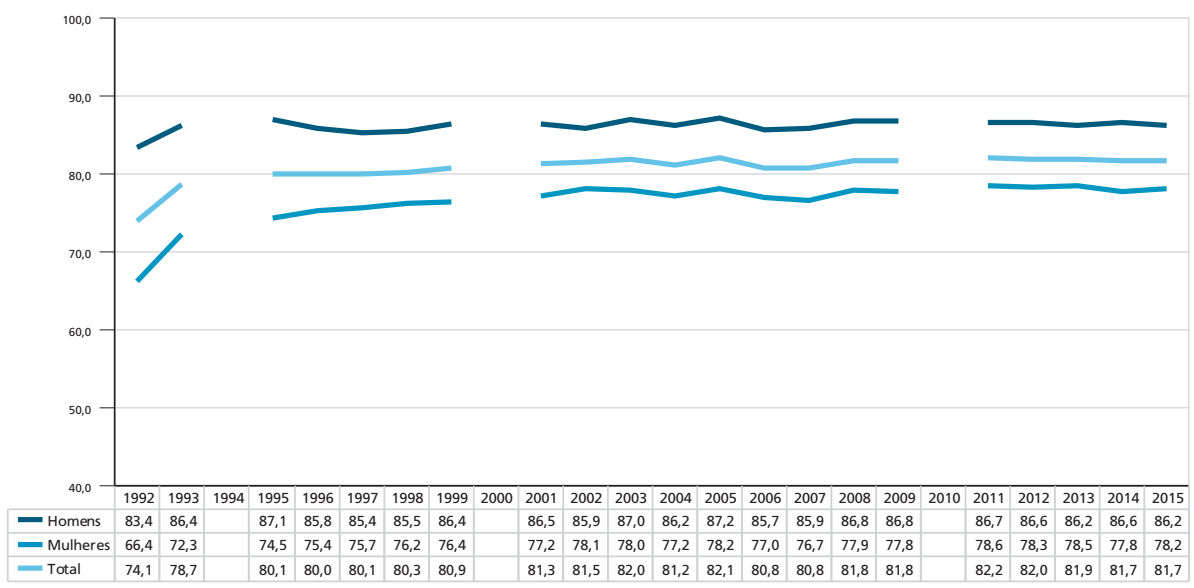

Fontes: Pnads/IBGE (vários anos).

Elaboração dos autores.

Nota: ${ }^{1}$ Nas séries harmonizadas, estão excluídas as áreas rurais da região Norte (salvo a área rural de Tocantins).

Obs.: Inclusive militares e estatutários.

O indicador desagregado por fator de proteção, naturalmente, reforça as diferenças marcantes existentes entre homens e mulheres, mas também aponta para tendências que reduzem as disparidades entre estes grupos. A proteção dos homens idosos é definida fundamentalmente pelo recebimento de benefícios próprios - principalmente aposentadorias, mas também BPC para idosos ou pessoas portadoras de deficiências. Esse fator, para os homens, permaneceu relativamente constante no horizonte temporal considerado (1992: 72,8\%; 2015: $72,4 \%)$. O percentual de homens que recebem apenas pensão por morte (1992: $0,6 \% ; 2015: 1,3 \%)$ ou que acumulam esse benefício com aposentadoria própria (1992: 0,3\%; 2015: 2,7\%) cresceu, em parte graças ao aumento da presença feminina no mercado de trabalho e no sistema previdenciário. Os contribuintes não beneficiários, apesar de muita oscilação ao longo da série histórica, encerram o período (2015: 9,9\%) com peso similar ao que possuíam em seu início (1992: 9,7\%).

14. 0 estatuto, vigente desde janeiro de 2004, reduziu (de 67 para 65 anos) a idade mínima para acesso ao benefício assistencial, além de ter flexibilizado o cálculo do limite máximo de um quarto de salário mínimo de renda familiar per capita, também necessário para a concessão do Benefício de Prestação Continuada previsto na Loas (Lei ํo 8.472, de 7 de dezembro de 1993). 


\section{GRÁFICO 7}

Decomposição do indicador de proteção previdenciária dos idosos, de 60 anos ou mais, segundo sexo - Brasil (1992-2015) ${ }^{1}$

(Em \%)

\section{$7 \mathrm{~A}-$ Homens}

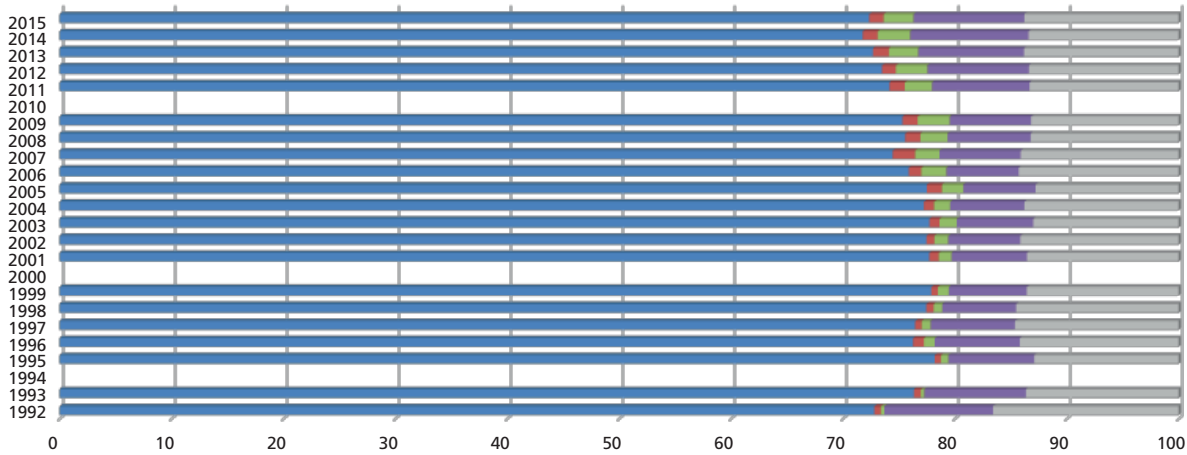

199219931994199519961997199819992000200120022003200420052006200720082009201020112012201320142015

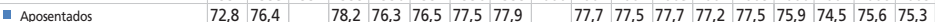

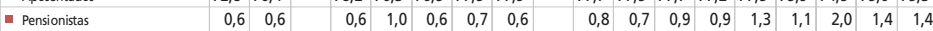

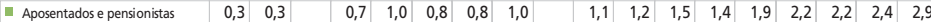

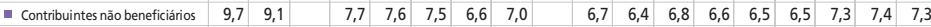

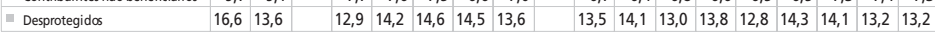

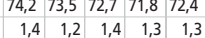

\section{B - Mulheres}

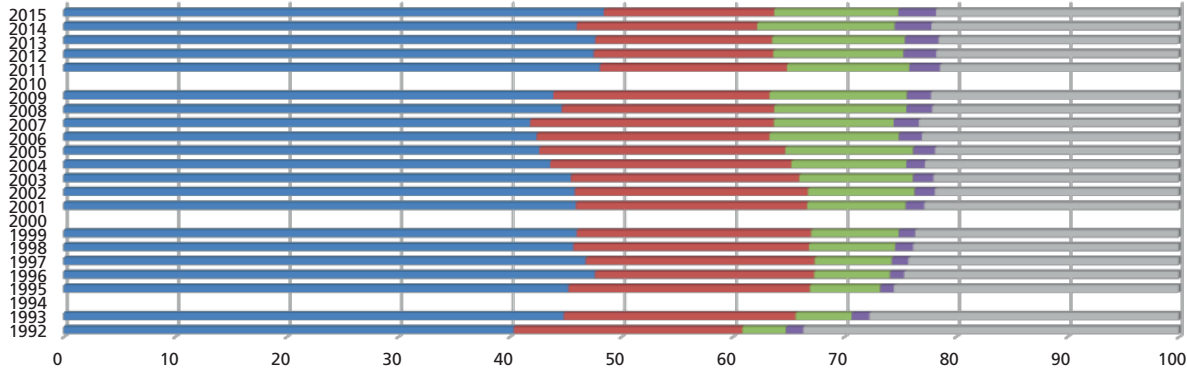

199219931994199519961997199819992000200120022003200420052006200720082009201020112012201320142015

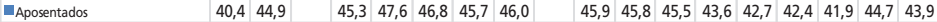
\begin{tabular}{l|r|l|l|l|l|l|l|l|l|l|l|l|l|l|l|l} 
MPensionistas & 20,5 & 20,8 & 21,7 & 19,7 & 20,5 & 21,2 & 21,0 & 20,7 & 20,9 & 20,5 & 21,6 & 22,1 & 20,9 & 21,8 & 19,0 & 19,4
\end{tabular}

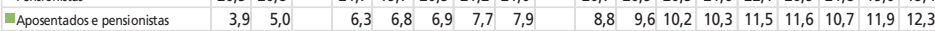




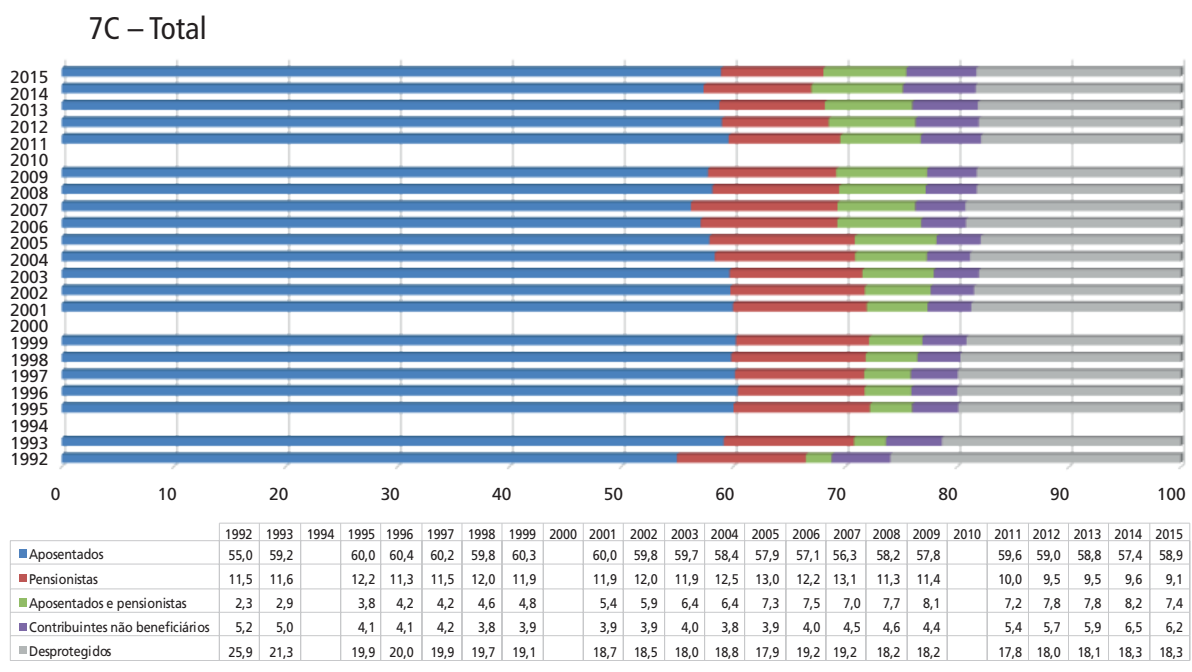

Fontes: Pnads/IBGE (vários anos).

Elaboração dos autores.

Nota: ${ }^{1}$ Exclusive áreas rurais da região Norte (salvo Tocantins).

Obs.: Figura reproduzida em baixa resolução e cujos leiaute e textos não puderam ser padronizados e revisados em virtude das condições técnicas dos originais (nota do Editorial).

Se os indicadores masculinos já apontam para isso, os femininos ainda mais fortemente indicam que há um movimento consistente de alteração no perfil de proteção dos idosos brasileiros. A proteção feminina também está mais intensamente atrelada ao recebimento de benefícios próprios do que a qualquer outro elemento, mas esse fator possui peso bastante inferior entre as mulheres idosas. Esse resultado ainda guarda relação com um estoque antigo de beneficiários da Previdência Social, formado em grande medida por indivíduos que possuíam idade ativa em época na qual os homens prevaleciam mais fortemente entre os economicamente ativos, os ocupados e os segurados dos regimes previdenciários.

O fluxo mais recente de entrada de indivíduos na população idosa tem sido acompanhado de aumento na proporção de mulheres apenas aposentadas $(1992: 40,4 \% ; 2015: 48,5 \%)$ ou que recebem aposentadoria e PPM (1992: 3,9\%; 2015: 11,1\%), segmentos que variaram (em pontos percentuais) mais que os equivalentes masculinos. Náo à toa, no período considerado, o percentual de mulheres que recebem apenas pensão por morte (1992: 20,5\%; 2015: 15,3\%) decresceu, ao passo que aumentou a proporção daquelas ainda não beneficiárias que seguem contribuindo para a previdência social (1992: 1,6\%; 2015: 3,4\%). Esses dados indicam que a cobertura da população idosa já começa a refletir, com a natural defasagem temporal, as mudanças observadas na cobertura da população ocupada. Resta observar como estas tendências se comportarão a médio e longo prazo, principalmente diante das profundas mudanças atualmente em discussão nas políticas assistencial, trabalhista e previdenciária. 


\subsection{Evolução do resultado previdenciário e do quantitativo de segurados (ativos e inativos)}

Em 2015, em valores correntes, a despesa previdenciária do RGPS alcançou aproximadamente $\mathrm{R} \$ 436,09$ bilhóes, enquanto suas receitas somaram pouco mais de $\mathrm{R} \$ 350$ bilhōes, gerando uma necessidade de financiamento de cerca de $\mathrm{R} \$ 85,82$ bilhóes. Nos RPPS e nos regimes específicos dos militares (reservistas e reformados), o resultado previdenciário agregado foi negativo em $\mathrm{R} \$ 121,63$ bilhôes, quadro gerado pelo confronto de uma despesa total de $\mathrm{R}$ \$232,98 bilhóes com receitas de $\mathrm{R}$ \$111,35 bilhóes no ano. Os resultados são preocupantes, inclusive para os RPPS municipais, mais recentes, nos quais prevalecem os segurados mais jovens e a relação entre contribuintes e beneficiários ainda não atingiu os níveis alarmantes observados nos demais sistemas.

TABELA 3

Quantitativo de segurados (contribuintes e benefícios ativos permanentes), receita, despesa e necessidade de financiamento da Previdência Social, segundo tipo de regime - Brasil (2015)

(Em R\$ bilhões correntes)

\begin{tabular}{|c|c|c|c|c|c|c|}
\hline \multirow{2}{*}{$\begin{array}{l}\text { Regime } \\
\text { previdenciário }\end{array}$} & \multicolumn{3}{|c|}{ Dados financeiros - resultado previdenciário } & \multicolumn{3}{|c|}{$\begin{array}{l}\text { Quantidade de contribuintes e beneficiários } \\
\text { permanentes }\end{array}$} \\
\hline & $\begin{array}{l}\text { Receita } \\
\text { (a) }\end{array}$ & $\begin{array}{l}\text { Despesa } \\
\text { (b) }\end{array}$ & $\begin{array}{c}\text { Resultado } \\
\text { previdenciário } \\
(\mathrm{a}-\mathrm{b})\end{array}$ & Aposentados & Pensionistas & Contribuintes \\
\hline RGPS & 350,27 & 436,09 & $-85,82$ & 18.526 .369 & 7.545 .905 & 53.539 .666 \\
\hline RPPS & 111,35 & 232,98 & $-121,63$ & 2.562 .196 & 1.042 .010 & 6.214 .947 \\
\hline União (civis) & 29,50 & 69,51 & $-40,01$ & 421.264 & 261.931 & 852.855 \\
\hline União (militares) & 2,65 & 35,16 & $-32,51$ & 151.022 & 148.022 & 363.914 \\
\hline Estados & 53,40 & 106,38 & $-52,98$ & 1.512 .306 & 497.208 & 2.574 .307 \\
\hline Municípios & 25,80 & 21,94 & 3,86 & 477.604 & 134.849 & 2.423 .871 \\
\hline Total & 461,62 & 669,07 & $-207,45$ & 21.088 .565 & 8.587 .915 & 59.754 .613 \\
\hline
\end{tabular}

Fontes: Anuário Estatístico da Previdência Social (AEPS/MF); Relatório Resumido de Execução Orçamentária (RREO/MF); Fluxo de Caixa/INSS; Boletim Estatístico de Pessoal/MP.

Elaboração dos autores.

Obs.: 1. Nos RPPS dos governos estaduais, as informações referem-se normalmente a servidores civis e militares, mas alguns entes federativos podem alterar essa configuração e/ou deixar de repassar (parcialmente ou integralmente) os dados de seus regimes. As contribuições patronal e da unidade gestora dos civis foram calculadas considerando-se o dobro do valor da contribuição do servidor ativo. Os valores de parte dos municípios foram incluídos por estimativa, pois os entes ainda não enviaram as informações. Como os dados podem ser revisados (atualizados e/ou corrigidos), estes podem diferir de informes apurados em outros momentos e circunstâncias. Os dados da União, relativos à quantidade de segurados, desconsideram o Fundo Constitucional do Distrito Federal.

2. A informação relativa ao RGPS consta do fluxo de caixa do Instituto Nacional do Seguro Social.

3. Com respeito ao RGPS, o estoque de benefícios consiste no total de benefícios ativos, em dezembro de 2015, em todas as espécies de aposentadorias e pensões por morte. Foram desconsiderados os benefícios temporários (auxílios variados, salário-maternidade e outros).

4. Os dados de contribuintes de 2014 e 2015 são preliminares, e serão atualizados no AEPS 2016. A quantidade de contribuintes corresponde a uma estimativa baseada nas pessoas que tiveram vínculo como contribuinte empregado ou contribuiçãa como contribuinte individual, empregado doméstico, contribuinte facultativo ou segurado especial no ano de referência. Tal estimativa corresponde à soma do número de meses com recolhimentos por cada pessoa, dividido por doze. 
O RGPS - maior componente do sistema previdenciário nacional - possui a maior participação na despesa previdenciária total, mas encontra-se sobrerrepresentado no montante total arrecadado a título de receita previdenciária. Isso implica que, em termos relativos e absolutos, o resultado previdenciário brasileiro (despesas subtraídas das receitas) se encontra bastante influenciado por desequilíbrios expressivos, financeiros e atuariais, em regimes próprios (de servidores públicos civis e, principalmente, militares) com um volume de beneficiários (diretos e indiretos) bem menos numeroso que o quantitativo registrado para o RGPS.

GRÁFICO 8

Participação dos regimes previdenciários, segundo ente da Federação, por componente do resultado previdenciário brasileiro (2015)

(Em \%)

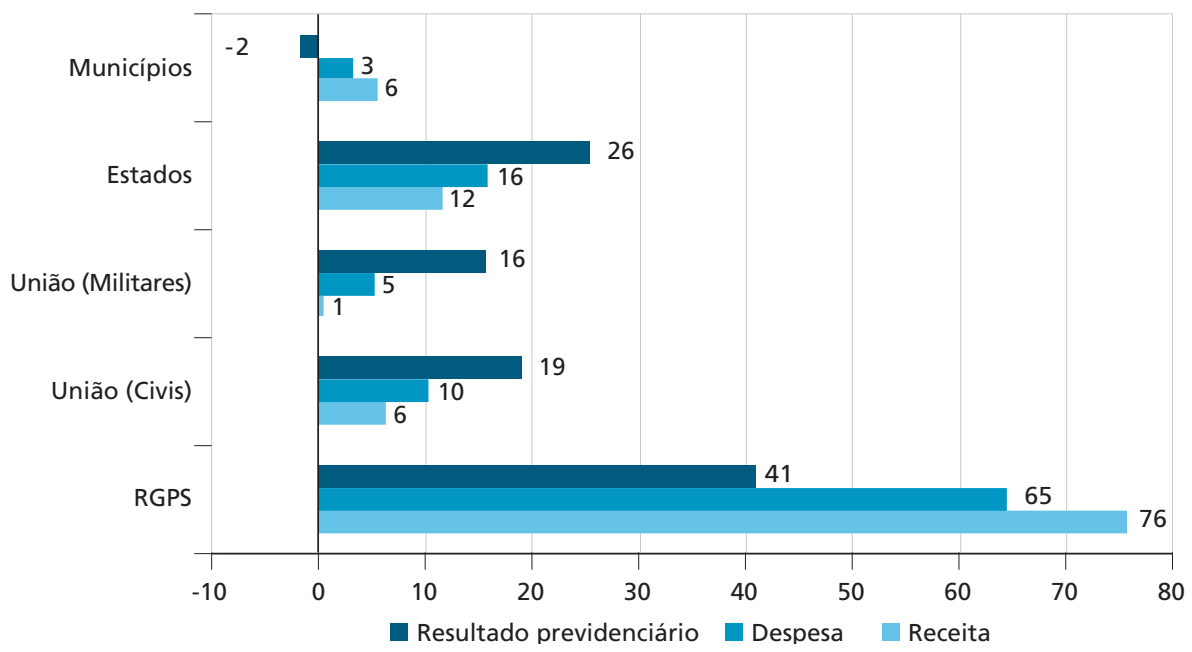

Fontes: AEPS/Ministério da Fazenda e RREO/MF.

Elaboração dos autores.

No RGPS, a receita previdenciária está atrelada mais diretamente à dinâmica registrada no mercado de trabalho brasileiro (volume de ocupados que contribuem para a Previdência Social e sua massa salarial correspondente), que por sua vez reflete - ainda que com alguma defasagem temporal - o contexto macroeconômico vivenciado pelo país. Pelo lado da despesa, os valores, naturalmente, são determinados pelo comportamento de três dimensóes fundamentais, relacionadas entre si: o estoque (evolução e composição do estoque) e o fluxo de entrada (novas concessões) e saída de benefícios (suspensôes e cessaçôes); a taxa de reposição dos benefícios previdenciários (relação entre o valor do benefício concedido e o salário de contribuição usado como referência para essa concessão); e a política de reajustamento destes (notadamente daqueles que equivalem ao piso previdenciário, valor preponderante entre os benefícios em estoque). 
$\mathrm{Na}$ última década, como resultado do bom momento vivido pela economia brasileira e de seus rebatimentos positivos no mercado de trabalho, houve forte aumento real da receita previdenciária líquida. No mesmo período, a expansão no estoque de benefícios e o aumento do valor médio destes foram determinantes para o aumento real da despesa - fatores estes, vale dizer, fortemente vinculados à evolução demográfica (marcada por um acelerado processo de envelhecimento populacional) e à política de valorização do salário mínimo (equivalente ao piso previdenciário), responsável (junto com a elevação real do rendimento médio do trabalho, referência para o cálculo dos benefícios) pela variação real positiva no valor médio dos benefícios pagos pelo RGPS. Não houve explosão no estoque de benefícios (gráfico 9), mas a quantidade anual de benefícios pagos cresce anualmente a taxas significativas e contínuas.

\section{GRÁFICO 9}

\section{Evolução do estoque de benefícios previdenciários ativos do RGPS, segundo grandes grupos de espécies - Brasil (2002-2015)}

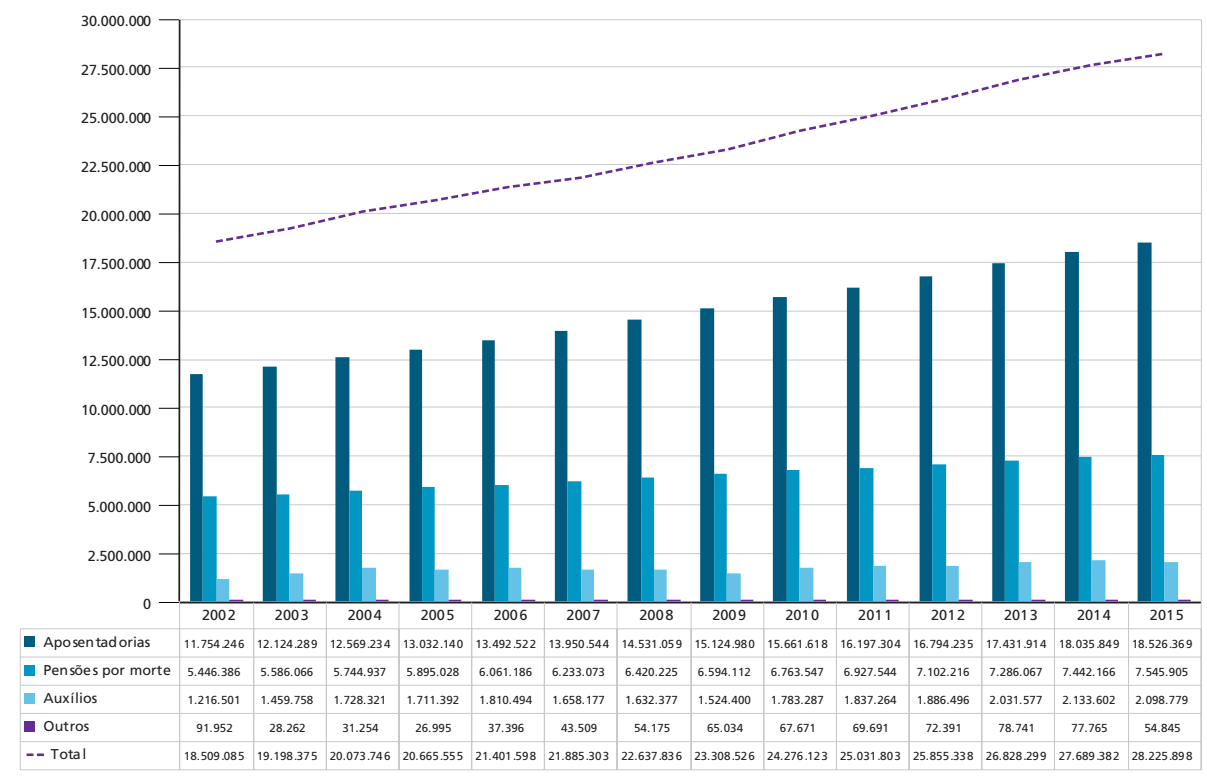

Fontes: Dados de 2002 a 2014, AEPS/MPS; e dados de 2015, AEPS/MF.

Elaboração dos autores.

No último biênio, em virtude da crise econômica enfrentada atualmente pelo país, os indicadores financeiros do RGPS se deterioraram ainda mais, com queda real da receita líquida e aumento real expressivo na necessidade de financiamento do sistema. Em virtude do baixo crescimento econômico, a política de reajustamento do salário mínimo (desde 2011), definida pela variação do produto interno bruto (PIB) do ano retrasado mais a inflação do ano anterior medida 
pelo Índice Nacional de Preços ao Consumidor (INPC), produziu impactos inferiores aos produzidos em anos anteriores, quando os ganhos concedidos ao piso previdenciário foram sistematicamente superiores à inflação.

GRÁFICO 10

Receita, despesa e resultado previdenciário do RGPS - Brasil (2005-2015)

(Em R\$ bilhões)'

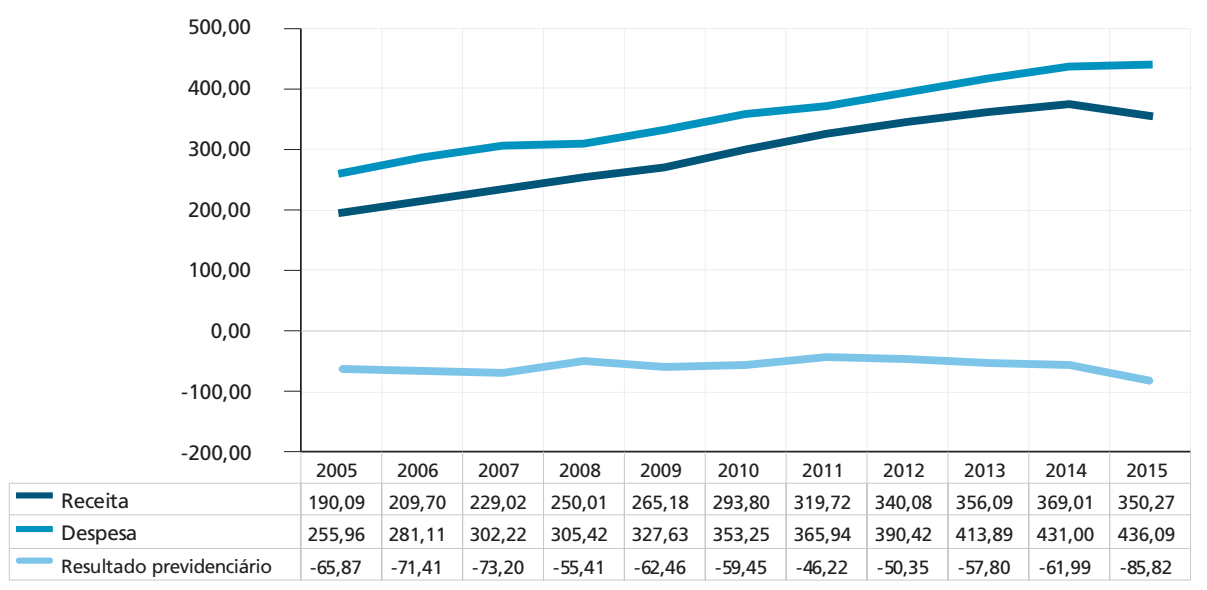

Fontes: Fluxo de Caixa/INSS e INPC/IBGE.

Elaboração dos autores.

Nota: ${ }^{1}$ Valores a preços médios de 2015 - INPC.

Com respeito aos regimes próprios de previdência social dos estados e do Distrito Federal, nota-se uma tendência de queda no volume de segurados ativos e de elevação na quantidade de beneficiários (notadamente, de aposentados). Nos RPPS municipais, os contingentes de ativos e inativos (aposentados) revelam tendência de expansão, ainda que entre os ativos o movimento seja aparentemente bem mais forte. Tais interpretações devem ser tomadas com cautela, contudo, uma vez que os dados oficiais, publicados pelo Ministério da Fazenda (anteriormente, pelo então Ministério da Previdência Social), oscilam muito no período. Tais oscilaçóes podem ser explicadas, em parte, por diferenças conceituais (por exemplo, pela inclusão, ou não, de policiais militares e bombeiros nestes quantitativos), imprecisôes e/ou atrasos nos informes obrigatórios preparados pelos diversos entes com regimes específicos. Para os regimes da União, de servidores civis e militares, também há quebras nas séries históricas (especialmente entre os pensionistas do regime militar), mas há uma leve tendência de elevação no número de servidores e militares ativos e de relativa estabilidade nos demais grupos (aposentados e pensionistas).

No curto prazo, a expansão no volume de servidores ativos pode representar algum alívio sobre o resultado previdenciário (via expansáo da receita), mas - para além de possíveis dificuldades para a sustentabilidade da despesa com pessoal 
ativo - a médio e longo prazos tal opção tenderá a se converter em aumentos na quantidade de beneficiários e, consequentemente, no aumento da despesa previdenciária. Esta observação é pertinente principalmente para os regimes próprios municipais, normalmente mais novos que os demais, nos quais a relação entre ativos e inativos (aposentados e pensionistas) ainda assume valores pouco preocupantes. Nos demais regimes, esta razão de dependência (razão entre contribuintes/ativos e beneficiários), embora tenha aumentado ligeiramente (via expansão do quadro de servidores ativos) nos últimos anos, já assume valor bastante reduzido e ameaça sua sustentabilidade.

Com respeito especificamente aos regimes próprios da União, nota-se uma tendência de relativa estabilidade nos resultados previdenciários, sem movimentos expressivos na despesa, na receita e na necessidade de financiamento. Apesar desse cenário de aparente estabilização, registrado no período 2010-2015, cumpre ressaltar que o resultado previdenciário anual ainda assume montante expressivo e com risco potencialmente elevado de insustentabilidade futura, quando os efeitos da transiçấo demográfica vivida pelo país se fizerem ainda mais presentes. Em outras palavras, o grau de desequilíbrio, que já preocupa no curto prazo, deverá ser intensificado nas próximas décadas.

\section{GRÁFICO 11}

Receita, despesa e resultado previdenciário dos RPPS da União (servidores civis e militares) - Brasil (2005-2015)

(Em R\$ bilhões) ${ }^{1}$

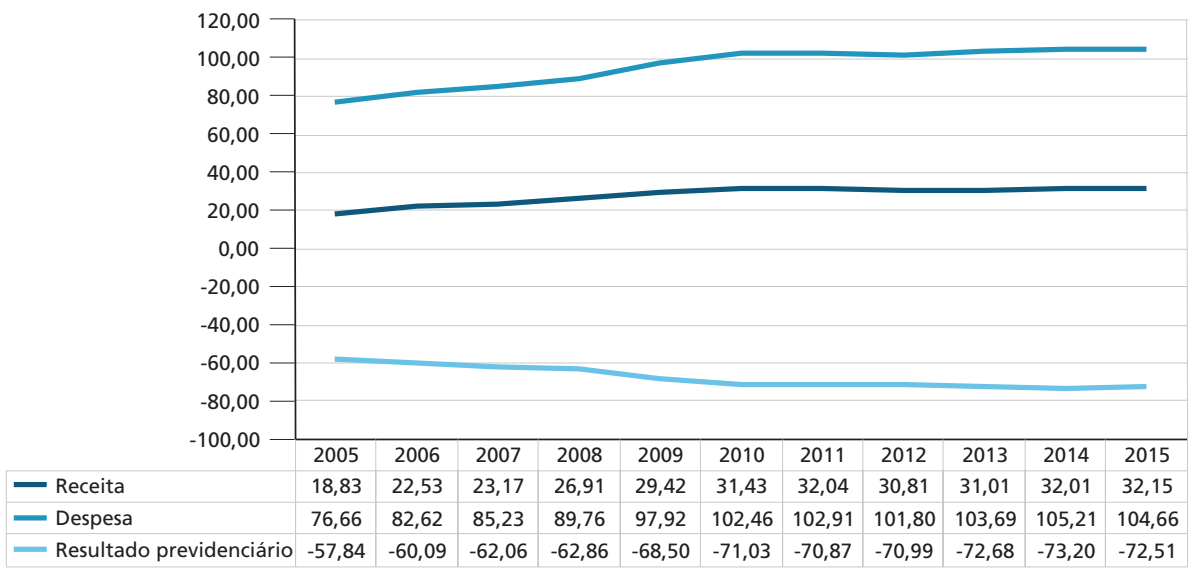

Fontes: RREO/Ministério da Fazenda; INPC/IBGE.

Elaboração dos autores.

Nota: ${ }^{1}$ Valores a preços médios de 2015 - INPC.

A Emenda Constitucional no 41/2003 foi desenhada para contribuir no enfrentamento desse desafio, entre outros pontos, por meio da instituição de regimes de previdência complementar, já implantados na União e em algumas 
UFs. Nestes casos, em que se fez a opção pela regulamentação dos regimes complementares, os benefícios pagos sob o regime de repartição simples (pay-as-you-go) foram limitados ao valor máximo pago mensalmente pelo RGPS. Os efeitos dessa medida devem ser sentidos no longo prazo, quando a transição entre os dois modelos for completada e a necessidade de financiamento for controlada e, possivelmente, diminuída. A curto e médio prazos, no entanto, pode-se observar inclusive alguma elevação nesse componente do resultado previdenciário, fruto deste custo de transição, que afetará inicialmente (e adversamente) a receita e apenas no futuro atingirá a despesa (quando porções crescentes dos inativos estiverem sujeitas ao teto previdenciário do RGPS).

Em conjunto (somados todos os regimes públicos de Previdência Social), a despesa previdenciária brasileira chegou, em 2015, a aproximadamente $11,33 \%$ do PIB. O patamar de despesa não parece tão destoante quando comparado unicamente com o mesmo indicador calculado para outros países, mas o desafio fica evidente quando a demografia é incluída na análise. Esse percentual, significativo em qualquer contexto, ganha ainda maior peso quando confrontado com a razão de dependência de idosos, estimada em 14,28 para o país (pela Pnad 2015).

Na comparação com 31 países europeus, para os quais a Eurostat (departamento oficial de estatística da União Europeia) compilou dados harmonizados entre si, nota-se que o nível de despesas brasileiras é excessivamente elevado quando se toma em conta o estágio de sua transição demográfica. O percentual do PIB brasileiro comprometido com o pagamento de benefícios previdenciários tende a ser superior àquele observado para países com razão de dependência assemelhada ou superior à brasileira. Ou seja, o destoante nível de gasto não pode ser suficientemente explicado pelo componente demográfico, para o qual se adotou como proxy a razão de dependência de idosos. 
GRÁFICO 12

Despesa previdenciária como proporção do PIB versus razão de dependência dos idosos - vários países europeus (2014) (inclusive militares); Brasil (2015) (RGPS, RPPS e militares)

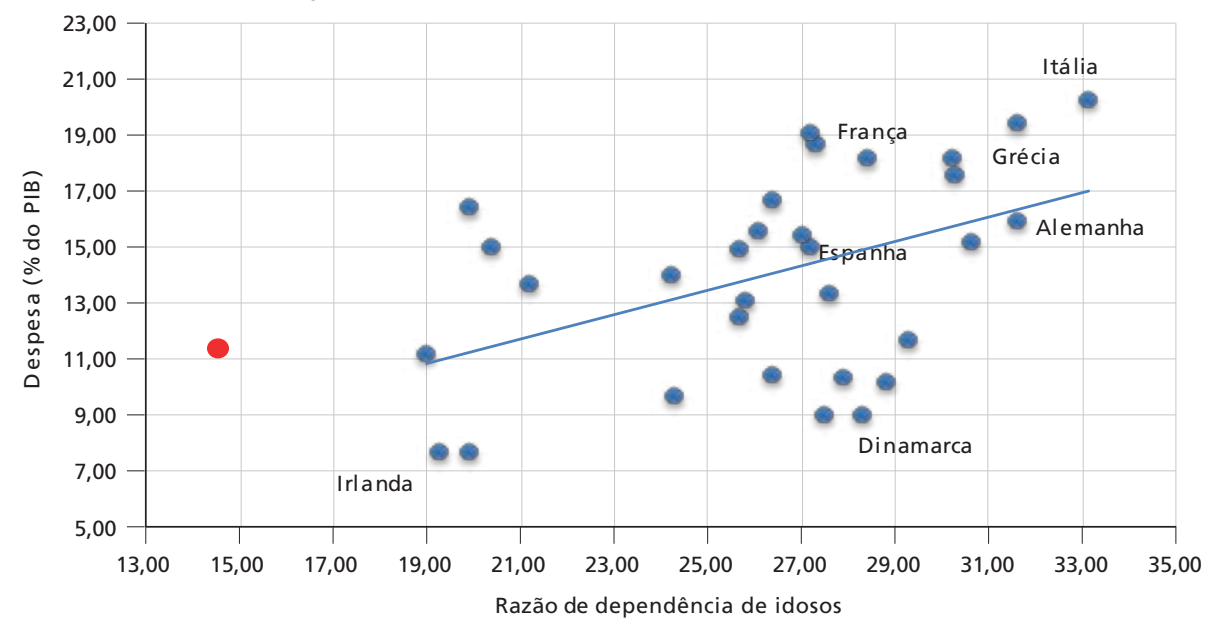

Fontes: AEPS/MF; RREO/MF; Fluxo de Caixa/INSS; Boletim Estatístico de Pessoal/MP; e Eurostat (disponível em: $<$ http://ec.europa.eu/eurostat/data/database>.

Elaboração dos autores.

Obs.: 1. A despesa consiste no total de repasses previdenciários, em dinheiro e por parte de todos os sistemas (inclusive de militares), concedidos sem qualquer requisito de renda (no means-tested). No Brasil, para os regimes próprios, consideram-se basicamente as despesas com aposentadorias e pensões por morte; para o RGPS, todos os benefícios são considerados; para os regimes europeus, são consideradas as aposentadorias (tradicionais e por invalidez), as pensões por morte e os auxilios-doença.

2. A razão de dependência demográfica de idosos é um indicador do contingente de possíveis dependentes ( 65 anos ou mais de idade) que é suportado pela população potencialmente produtiva (idade entre 15 e 64 anos).

3. Os dados do Brasil foram desconsiderados na estimativa da reta, tanto por serem extremos e influenciarem demasiadamente os coeficientes da regressão, como também porque o objetivo do exercício é justamente comparar a situação brasileira com a média europeia.

4. Os dados da Eurostat fazem referência aos seguintes países: Bélgica, Bulgária, República Checa, Dinamarca, Alemanha, Estônia, Irlanda, Grécia, Espanha, França, Croácia, Itália, Chipre, Letônia, Lituânia, Luxemburgo, Hungria, Malta, Holanda, Áustria, Polônia, Romênia, Eslováquia, Eslovênia, Finlândia, Suécia, Reino Unido, Islândia, Noruega e Suiça.

Apesar de diferenças óbvias entre o Brasil e o conjunto desses países, ${ }^{15} \mathrm{a}$ comparação apresentada é pertinente pela relativa convergência do grau de cobertura de idosos nessas naçóes, bem como pela perspectiva de interesse, justamente a de longo prazo. Nos países europeus, em geral, a transição demográfica já ocorreu e foi acompanhada (com maior ou menor aderência temporal) por transformaçóes na estrutura de benefícios e serviços públicos oferecidos aos indivíduos e às famílias, adaptando-a às necessidades de sociedades agora envelhecidas. As iniciativas governamentais brasileiras, nesse contexto mais amplo, são menos robustas e, sem reformulaçôes e incrementos, dificilmente poderão fazer frente à mudança

15. Trata-se de países com renda alta, estágio de desenvolvimento social mais elevado e sistemas previdenciários com características distintas, na comparação com o brasileiro (marcado, por exemplo, pelas peculiaridades da previdência rural), mas que possuem patamar de cobertura semelhante ao brasileiro (diferentemente da América Latina e do Caribe) e, em geral, funcionam sob a lógica de seguro social. 
na estrutura demográfica do país, mas deve-se considerar que o Brasil dispõe de menos recursos que os países desenvolvidos para o financiamento de políticas sociais, de qualquer natureza.

Outro ponto importante diz respeito à velocidade e ao momento em que os diferentes grupos de países enfrentaram ou enfrentarão mudanças demográficas mais dramáticas. No país, o envelhecimento populacional (tomando-se como referência a proporção de idosos com 60 anos ou mais na população) se dará em ritmo mais intenso que o já observado nos países europeus e, estas naçóes, em sua maioria, enfrentaram esse fenômeno quando já possuíam patamar de riqueza e desenvolvimento mais elevado. ${ }^{16} \mathrm{Ou}$ seja, o Brasil terá possivelmente menos tempo e menos recursos disponíveis para os ajustes necessários à sustentabilidade do sistema previdenciário. Essas comparaçóes são fundamentais para o entendimento dos desafios a serem enfrentados pelo país.

\section{CONSIDERAÇÕES FINAIS}

Até recentemente, o Brasil era considerado um país jovem e, como tal, a demografia atuava a favor do sistema previdenciário brasileiro, com mais pessoas contribuindo do que pessoas beneficiárias. Contudo, acompanhando uma tendência mundial, o Brasil está envelhecendo de forma rápida e intensa e o desafio de garantir os direitos das geraçóes mais jovens no futuro passa necessariamente pela sustentabilidade do sistema a médio e longo prazo. No caso brasileiro, os efeitos do envelhecimento tendem a ser ampliados por distorçóes como ausência de idade mínima e componentes regressivos como os benefícios de valores elevados dos regimes de previdência dos servidores públicos. Neste sentido, parece fundamental uma reforma da Previdência que consiga garantir a sustentabilidade a médio e longo prazo, sem comprometer uma elevada cobertura nem o papel da Previdência no combate à pobreza, em especial, para a população idosa.

Os dados da Pnad mostram que atualmente a maioria dos idosos conta com a proteção social da Previdência. A parcela da população idosa protegida passou de $74,1 \%$ em 1992 para 81,7\% em 2015. Se considerarmos a parcela de 16 a 59 anos, $72,5 \%$ da população ocupada está protegida. Portanto, o Brasil avançou no processo de aumento da cobertura previdenciária. Embora ainda existem desafios importantes a serem superados, em especial, para determinados públicos específicos, como os trabalhadores por conta própria, os resultados obtidos de 2003 a 2015 foram positivos. Claro, contudo, que o processo de profunda recessão pelo qual o país passou representou uma interrupção na tendência de aumento da cobertura previdenciária. Será fundamental a retomada do crescimento econômico sustentado para voltar a tendência de incremento da cobertura previdenciária.

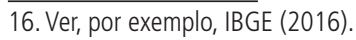


Os avanços em termos de cobertura contrastam com dificuldades de manutenção da sustentabilidade do sistema. Neste ponto, em que pese às profundas polêmicas inerentemente associadas a processos de reforma previdenciária, deve-se pelo menos haver a clareza de necessidade da reforma e a importância de conseguir buscar acordos entre os Poderes Executivo e Legislativo e no âmbito da sociedade que permita a busca dos objetivos de um sistema previdenciário sustentável, com elevada cobertura e efetivo no combate à pobreza, em especial, entre a população idosa.

\section{REFERÊNCIAS}

GROSSI, M. E.; SILVA, J. G.; CAMPANHOLA, C. O fim do êxodo rural? Espaço e Geografia, v. 4, n. 1, p. 37-56, jan./jun., 2001.

IBGE - INSTITUTO BRASILEIRO DE GEOGRAFIA E ESTATÍSTICA. Atlas Nacional do Brasil Milton Santos. Rio de Janeiro: IBGE, 2010.

. Pesquisa Nacional por Amostra de Domicílios (Pnad) 2015. Rio de Janeiro: IBGE, 2015.

. Coordenação de população e indicadores sociais. Síntese de indicadores sociais: uma análise das condiçôes de vida da população brasileira. Rio de Janeiro: IBGE, 2016.

. Pesquisa Nacional por Amostra de Domicílios (Pnad). Rio de Janeiro: IBGE. Vários anos.

STF - SUPREMO TRIBUNAL FEDERAL. Recurso Extraordinário no 661256. Conversão de aposentadoria proporcional em aposentadoria integral por meio do instituto da desaposentação. Brasília, 2016. Disponível em: <https://goo.gl/Ps9Pje>. ZANELLA, A. J.; CARVALHO, J. V. F.; AFONSO, L. E. Quais os impactos da desaposentação? Um estudo para as aposentadorias por tempo de contribuição do Regime Geral de Previdência Social. Estudos Econômicos, São Paulo, v. 44, n. 4, p. 723-748, 2014. 


\section{NOTAS METODOLÓGICAS}

Para facilitar a compreensão e a interpretação dos dados/indicadores apresentados, as definiçôes e as metodologias de cálculo utilizadas na geração das tabelas são descritas a seguir.

Nas tabelas 6.1 - Quantidade e valor de benefícios emitidos no INSS, segundo espécie, e 6.2 - Quantidade e valor de benefícios concedidos no INSS, segundo espécie, os seguintes conceitos são utilizados:

Benefícios emitidos: correspondem aos créditos emitidos para pagamento de benefícios, ou seja, são benefícios de prestação continuada que se encontram ativos no cadastro e para os quais são encaminhados créditos junto à rede pagadora de benefícios. Os dados de quantidade incluem as pensões alimentícias e os desdobramentos de pensóes por morte.

Valor dos benefícios emitidos: corresponde ao valor líquido do benefício, obtido pela diferença entre o valor bruto (valor do benefício adicionado de complementos etc.) e o valor dos descontos (imposto de renda, pensão alimentícia, créditos consignados etc.), posicionado em dezembro do respectivo ano.

Benefícios previdenciários: são aqueles que têm por objetivo repor a renda do segurado; sua concessão se dá em troca de contribuição - como é o caso da previdência urbana - ou equivalente - caso da previdência rural -, quando há ocorrência de um dos "riscos sociais" segurados pela Previdência Social (idade, invalidez, maternidade, encargos familiares etc.). Os benefícios acidentários não estáo incluídos neste grupo.

Benefícios acidentários: devidos ao segurado acidentado, ou ao(s) seu(s) dependente(s), quando o acidente ocorre no exercício do trabalho a serviço da empresa, equiparando-se a este a doença profissional ou do trabalho ou, ainda, quando sofrido no percurso entre a residência e o local de trabalho, provocando lesão corporal ou perturbação funcional que cause a morte ou a redução da capacidade para o trabalho. Os benefícios acidentários classificam-se em aposentadoria, pensão por morte, auxílio-doença e auxílio-acidente.

Benefícios assistenciais: benefícios monetários que não pressupõem a existência de contribuição prévia, assumindo as espécies de renda mensal vitalícia (não mais concedida desde 31 de dezembro de 1995, por força da Lei no 8.742 , de 1993), amparo assistencial (previsto na Lei no 8.742, de 1993, a Lei Orgânica da Assistência Social (LOAS)) e pensão mensal vitalícia (criada pela Lei no 7.986, de 1989, e devida ao seringueiro (e ao(s) seu(s) dependente(s)) que trabalhou durante a Segunda Guerra Mundial nos seringais da região Amazônica e que não possui meios para sua subsistência). A concessão de amparos assistenciais, benefícios que prevalecem na concessão e no estoque do INSS, se dá após a verificação da situação 
de carência do candidato ao benefício, que consiste, no caso do Benefício de Prestação Continuada (BPC) - identificado como "amparo assistencial" nas tabelas do Instituto Nacional do Seguro Social (INSS) -, na comprovação de rendimento familiar per capita igual ou inferior a um quarto do salário mínimo vigente.

Encargos previdenciários da União: benefícios de aposentadoria e pensóes dos servidores civis e militares da administração direta da Uniâo e benefícios concedidos através de leis especiais, que são pagos pelo INSS com recursos da União. Inclui as espécies: pensão por morte estatutária; pensão especial (Lei no 593/1948); aposentadoria de extranumerário da União; aposentadoria da extinta CAPIN; pensão mensal vitalícia por síndrome de talidomida; aposentadoria excepcional de anistiado; pensão por morte excepcional do anistiado; e pensão especial à vítima da hemodiálise Caruaru. Em geral, consistem em benefícios concedidos a grupos restritos da população, principalmente como forma de compensá-los por danos sofridos em nome do país ou em reconhecimento de serviços prestados à coletividade. As pensôes mensais vitalícias pressupóem lei do Congresso Nacional que as conceda.

Benefícios concedidos: correspondem às solicitações de benefício deferidas e liberadas para pagamento, após o cumprimento por parte do segurado dos requisitos estabelecidos em lei, e, portanto, ao fluxo de entrada de novos benefícios no sistema previdenciário.

As tabelas 6.3 a 6.5 trazem indicadores de cobertura da previdência:

6.3a - Cobertura dos idosos com benefícios de algum regime público de previdência: proporção (em porcentagem) de idosos com 60 anos ou mais que recebem aposentadoria e/ou pensão de algum regime de previdência pública básica - INSS e Previdência do Servidor Público. O conceito de idoso (60 anos ou mais) corresponde àquele constante do Estatuto do Idoso (Lei no 10.741/2003). Para se obter este dado de cobertura a partir dos microdados da PNAD/IBGE, há necessidade de se eliminar a dupla contagem naqueles casos em que a mesma pessoa acumula aposentadoria e pensão, uma vez que esta situação é legalmente possível.

$6.3 b$ - Cobertura de domicílios com população idosa que recebe benefício de regime público de previdência: proporção (em porcentagem) de domicílios que tenham entre seus membros idosos com 60 anos ou mais que recebem aposentadoria e/ou pensão de algum regime de previdência pública básica - INSS e Previdência do Servidor Público. Para se obter este dado de cobertura a partir dos microdados da PNAD, há necessidade de se eliminar a dupla contagem naqueles casos em que a mesma pessoa acumula aposentadoria e pensão, uma vez que esta situação é legalmente possível. 
6.4 - Proporção de contribuintes na população economicamente ativa, população-alvo do INSS e regimes próprios do funcionalismo público e militar, segundo sexo e raça ou cor - Brasil e grandes regiōes (1992-2015)

Proporção de contribuintes na população economicamente ativa restrita: percentual de pessoas economicamente ativas, ocupadas em atividades potencialmente cobertas pela CLT e contas-próprias (populaçáo-alvo do INSS) ou estatutários e militares (regimes próprios de Previdência) que contribuem (ou possuem contribuição presumida, em função do vínculo empregatício formal) para algum sistema público de previdência básica. Apresenta-se tanto o dado restrito à população ocupada no setor privado - exclui funcionários públicos estatutários e militares -, quanto o relativo à soma dos setores privado e público.

6.5 - Cobertura direta e indireta da previdência pública básica na população em idade ativa, segundo sexo e raça ou cor - Brasil e grandes regióes (1992-2015)

Proporção de pessoas em idade ativa na população, cobertas direta ou indiretamente pelo seguro social: é retratada pela porcentagem de pessoas em idade ativa seguradas pela previdência, conforme conceito amplo de cobertura, sob alguma das seguintes situaçôes:

a) a pessoa contribui na ocupação atual ou contribuiu em algum dos últimos doze meses - conceito da Organização Internacional do Trabalho (OIT); observe-se que, no caso dos dados da PNAD, somente é possível apurar tal informação para pessoas que possuíam emprego assalariado nos últimos doze meses, não sendo possível apurá-lo para contribuintes individuais;

b) a pessoa está ocupada em atividade coberta pela previdência rural;

c) a pessoa que, caso não contribua, possui cônjuge que contribui na ocupação atual ou que contribuiu em algum dos últimos doze meses;

d) a pessoa que, caso não seja coberta pela previdência rural, possui cônjuge coberto por esta; ou

e) a pessoa, se inativa, é filho/dependente legal de até 18 anos (ou 21 anos, se estudante) de pessoa coberta pela previdência rural ou que contribuiu pelo menos uma vez nos últimos doze meses.

A tabela 6.6 traz indicadores básicos sobre as Entidades Fechadas de Previdência Complementar (EFPC), entidades sem fins lucrativos, constituídas pelo patrocinador ou instituidor, sob a forma de sociedade civil ou fundação, que têm por objetivo administrar e executar planos de benefícios de natureza previdenciária. As EFPC, para efeito de normatização, orientação e fiscalização, encontram-se sob a área de atuação governamental afeta à Previdência Social. Os seguintes conceitos básicos são utilizados: 
População total: soma do total de participantes, assistidos, designados e beneficiários de pensão, amparados pelo plano de benefícios.

Participante: aquele que adere ao plano de benefícios de caráter previdenciário.

Assistido: participante ou seu beneficiário em gozo de benefício de prestação continuada, previsto no plano de benefícios.

Beneficiário: aquele indicado pelo participante para gozar de benefício de prestação continuada.

Designado: pessoa indicada pelo participante ou assistido, que poderá ter direito a benefícios, de acordo com as regras estabelecidas no regulamento do plano de benefícios.

Patrocinador: empresa ou grupo de empresas, União, estados, Distrito Federal e municípios, suas autarquias, fundaçóes, sociedades de economia mista e outras entidades públicas que instituam, para seus empregados ou servidores, plano de benefícios de caráter previdenciário, por intermédio de entidade fechada.

Instituidor: pessoa jurídica de caráter profissional, classista ou setorial, que oferece aos seus associados ou membros, plano de benefícios de natureza previdenciária, operado por EFPC, sem finalidade lucrativa. 


\section{TABELAS ${ }^{1}$}

6.1 Quantidade e valor de benefícios emitidos no INSS, segundo espécie - Brasil (1995-2014)

6.2 Quantidade e valor de benefícios concedidos no INSS, segundo espécie - Brasil (1995-2014)

6.3a Cobertura da população idosa que recebe benefício de aposentadoria e/ou pensão, segundo sexo e raça ou cor - Brasil e grandes regióes (1992-2015) (Em \%)

6.3b Cobertura dos domicílios com população idosa que recebe benefício de aposentadoria e/ou pensão - Brasil e grandes regióes (1992-2015)

$(\mathrm{Em} \%)$

6.4 Proporção de contribuintes na população economicamente ativa, população-alvo do INSS e regimes próprios do funcionalismo público e militar, segundo sexo e raça ou cor - Brasil e grandes regióes (1992-2015)

$(\mathrm{Em} \%)$

6.5 Cobertura direta e indireta da previdência pública básica na população em idade ativa, segundo sexo e raça ou cor - Brasil e grandes regióes (1992-2015) (Em \%)

6.6 Previdência complementar fechada - entidades, tipo de patrocinadores, população coberta, benefícios pagos e composição da carteira de investimentos - Brasil (1996-2014) 
Ipea - Instituto de Pesquisa Econômica Aplicada

\section{Assessoria de Imprensa e Comunicação}

\section{EDITORIAL}

\section{Coordenação}

Cláudio Passos de Oliveira

\section{Supervisão}

Everson da Silva Moura

Leonardo Moreira Vallejo

\section{Revisão}

Ana Clara Escórcio Xavier

Camilla de Miranda Mariath Gomes

Clícia Silveira Rodrigues

Idalina Barbara de Castro

Olavo Mesquita de Carvalho

Regina Marta de Aguiar

Reginaldo da Silva Domingos

Alice Souza Lopes (estagiária)

Hislla Suellen Moreira Ramalho (estagiária)

Isabela Monteiro de Oliveira (estagiária)

Lilian de Lima Gonçalves (estagiária)

Lynda Luanne Almeida Duarte (estagiária)

Luiz Gustavo Campos de Araújo Souza (estagiário)

Polyanne Alves do Santos (estagiária)

\section{Editoração}

Aeromilson Trajano de Mesquita

Bernar José Vieira

Cristiano Ferreira de Araújo

Danilo Leite de Macedo Tavares

Herllyson da Silva Souza

Jeovah Herculano Szervinsk Junior

Leonardo Hideki Higa

\section{Capa}

Danielle de Oliveira Ayres

Flaviane Dias de Sant'ana

The manuscripts in languages other than Portuguese

published herein have not been proofread.

\section{Livraria Ipea}

SBS - Quadra 1 - Bloco J - Ed. BNDES, Térreo

70076-900 - Brasília - DF

Tel.: (61) 2026-5336

Correio eletrônico: livraria@ipea.gov.br 

Composto em adobe garamond pro 11/13,2 (texto) Frutiger 67 bold condensed (títulos, gráficos e tabelas) Brasília-DF 



\section{Missão do Ipea}

Aprimorar as políticas públicas essenciais ao desenvolvimento brasileiro por meio da produção e disseminação de conhecimentos e da assessoria ao Estado nas suas decisões estratégicas. 